\title{
The importance of ants in cave ecology, with new records and behavioral observations of ants in Arizona caves
}

\author{
Robert B. Pape \\ Department of Entomology, University of Arizona, Tucson, Arizona 85721-0036, USA
}

\begin{abstract}
The importance of ants as elements in cave ecology has been mostly unrecognized. A global list of ant species recorded from caves, compiled from a review of existing literature, is presented. This paper also reviews what is currently known about ants occurring in Arizona (USA) caves. The diversity and distribution represented in these records suggests ants are relatively common cave visitors (trogloxenes). A general utilization of caves by ants within both temperate and tropical latitudes may be inferred from this combined evidence. Observations of ant behavior in Arizona caves demonstrate a low level and sporadic, but persistent, use of these habitats and their contained resources by individual ant colonies. Documentation of Neivamyrmex sp. preying on cave-inhabiting arthropods is reported here for the first time. Observations of hypogeic army ants in caves suggests they may not penetrate to great vertical depth in search of prey, but can be persistent occupants in relatively shallow, horizontal sections of caves where they may prey on endemic cave animals. First cave records for ten ant species are reported from Arizona caves. These include two species of Neivamyrmex (N. nigrescens Cresson and Neivamyrmex sp.; Formicidae: Dorylinae), four myrmicines (Pheidole portalensis Wilson, Pheidole cf. porcula Wheeler, Solenopsis aurea Wheeler and Stenamma sp. Westwood), one dolichoderine (Forelius keiferi Wheeler) and three formicines (Lasius arizonicus Wheeler, L. sitiens Wilson, and Camponotus sp. Mayr).
\end{abstract}

Keywords: $\quad$ ants, cave ecology, Formicidae, trogloxene

Received 28 June 2015; Revised 13 June 2016; Accepted 14 June 2016

Citation: $\quad$ Pape R.B., 2016. The importance of ants in cave ecology, with new records and behavioral observations of ants in Arizona caves. International Journal of Speleology, 45 (3), 185-205. Tampa, FL (USA) ISSN 0392-6672 http://dx.doi.org/10.5038/1827-806X.45.3.1936

\section{INTRODUCTION}

The importance of ants as elements in the ecology of caves has been mostly unrecognized (Bellés, 1987; Tinaut \& Lopez, 2001; Sendra et al., 2011) and historically, research has focused on determining if there are any truly troglobiotic ant species (Kempf, 1961; Wilson, 1962; Tinaut, 2001; Roncin \& Deharveng, 2003). Due, in part, to the search for cave-adapted ants, the importance of individual ant colonies utilizing caves has not received adequate attention. The few researchers that have treated ants generally as potentially important elements in cave ecology include Peck, in his studies of caves in the Caribbean (Peck, 1974; 1981a; 1981b; 1982; 1992), Reddell \& Cokendolpher (2001) and Cokendolpher et al. (2009) in similar studies in Belize, Mexico, and California and Texas in the USA, and Roncin \& Deharveng (2003) in Laos. The great majority of ants occurring in caves probably function as trogloxenes, and it is in this capacity that their importance in cave ecology lies.
Arizona (USA) has a significant cave resource, with approximately 1,500 known caves, but our knowledge of arthropods in caves in the state is very limited (Pape, 2014; Pape \& OConnor, 2014). This paper reviews what is currently known about ants occurring in Arizona caves. The first record of an ant in an Arizona cave was not reported until 1999, when Muchmore \& Pape (1999) mentioned a Monomorium sp. Mayr from Arkenstone Cave near Vail, Arizona. This record is now known to actually be Pheidole cf. porcula Wheeler (this paper). Ten years passed before a second ant record appeared in Shear et al. (2009), for Camponotus ocreatus Emery from Cathedral Cave in northern Arizona. Wynne \& Voyles (2014) reported four ant species from caves in the Grand Canyon-Parashant National Monument in Mohave County, Arizona. And most recently, studies in Kartchner Caverns at Kartchner Caverns State Park (KCSP) near Benson, Arizona added an additional five species to the list of ants found in Arizona caves (Pape $\&$ OConnor, 2014).

This paper provides a literature summary of ant species recorded from caves around the World, with 
new data from Arizona. Important elements of this data are the records and ecology of Neivamyrmex found in caves, including their predation on endemic cave arthropods. The sum of this data demonstrates the importance of individual ant colonies in the cave ecology, behavior that is probably global in extent.

\section{MATERIALS AND METHODS}

\section{Literature review}

A list of ant species recorded in caves was compiled from a review of existing literature, and is presented in Appendix A. Multiple cave records for species (such as the hundreds of records for Solenopsis invicta Buren from caves in Texas) have not all been included. Rather, the list was constructed with the intent of listing all genera and species reported from caves, and to assemble the known distribution of cave occurrences for each species. The cave ecological group assigned to these occurrences, when provided by the recording author(s), is included in Appendix A using their original terminology.

There is a long history of efforts to define the ecological associations of terrestrial cave animals, which have been summarized by several authors including Vandel (1965), Camacho (1992) and Sket (2008). To date the issue seems to not be satisfactorily resolved to the satisfaction of all (Romero, 2009, 2011; Lunghi et al., 2014; Pape, this paper), but the definitions proposed by Sket (2008) seem to be gaining greater acceptance among biospeleologists. I use the following definitions (modified after Sket, 2008) in the body of this paper. A troglobiont is an obligate cave animal, which cannot live outside of the cave environment. A eutroglophile is a facultative cave animal that is capable of completing its life cycle within caves, but may also do so in similar habitats. A subtroglophile is an animal that has a proclivity for regularly using caves to meet one or more of its ecological needs, such as food, water, shelter, etc., but must return to the epigean environment to meet some required life cycle need(s). A trogloxene is an animal that opportunistically uses cave resources that occur within its territory. The term incidental (rather than "accidental") is reserved for animals that randomly enter a cave, and that derive no ecological benefit from their presence in these habitats.

Taxonomy follows ANTCAT (Bolton, 2014) and phylogenetic sequence follows Ward (2014).

\section{Field studies}

Field studies for this paper consisted of in-cave biological surveys conducted in 35 caves in Arizona spanning 25 years. Surveys were conducted to document all macrobiotic resources, and did not specifically target ants. Search effort varied considerably, ranging from a couple of hours during a single visit to an individual cave (as at Porcupine Cave) to more extensive efforts involving numerous visits to a single cave over many years (as at Arkenstone Cave, with approximately 500 in-cave hours during 124 visits over 14 years, and supplemented by observations at the cave entrance during related studies). Surveys consisted of searching human-accessible portions of caves, turning over floor debris including small rocks, broken cave formations, and organic debris, and searching dead animals, scat and bat guano deposits. No pitfall traps were employed. Baits, consisting of raw wood blocks, were used only during the recent two-year Kartchner Caverns study (Pape \& OConnor, 2014). Since field studies in most of the caves were concerned primarily with establishing baseline biological inventories, no quantitative measurements of available nutrients were performed.

Most caves in Arizona contain sensitive archaeological, paleontological, biological or mineralogical resources, or some combination of these constituents. Few of these sites have adequate protections in place to protect these resources. Due to the presence of sensitive resources and the limited value of the negative findings at 29 of the studied caves, many of which were only visited once, they are not named in this paper. Descriptions are provided below for the six caves where ants were found during the field studies and for one previous record (at Cathedral Cave), for which such information was available.

\section{Cave descriptions}

- Arkenstone Cave is a designated research site located within Colossal Cave Mountain Park 37 $\mathrm{km}$ southeast of Tucson, near Vail, Arizona. The cave is situated in Arizona Upland Subdivision Sonoran Desertscrub (Turner \& Brown, 1982) at $1,112 \mathrm{~m}$ asl. The cave is formed in Paleozoic age (370-260 mya) limestone strata, and is approximately $1,000 \mathrm{~m}$ in length. The cave supports several endemic troglobiotic arthropods (Muchmore \& Pape, 1999).

- Kartchner Caverns State Park, near Benson, Arizona, lies within the Basin and Range Province physiographic region of the western United States, and is situated in the Semidesert Grassland biotic community (Brown \& Makings, 2014). Kartchner Caverns is contained within a grouping of small hills situated low on the east flank of the Whetstone Mountains, and is formed in the Mississippian age (359-318 mya) Escabrosa Limestone (Jagnow, 1999). The cave is $1,428 \mathrm{~m}$ above sea level (asl), and is approximately three kilometers in length (Fig. 1). Kartchner Caverns supports a maternity colony of the cave myotis (Myotis velifer Allen) and a large and diverse suite of invertebrates, including several endemic troglobionts (Welbourn, 1999; Pape \& OConnor, 2014).

- Hidden Cave is a small cave on the east side of the Santa Rita Mountains in Santa Cruz County, Arizona. The cave is situated in Madrean Evergreen Woodland (Brown, 1982a), at 1,613 m asl, and its entrance overlooks a small, ephemeral riparian drainage. The cave is developed in the Mississippian age Escabrosa Limestone.

- Porcupine Cave is situated in Petran Montane Conifer Forest (Pase \& Brown, 1982) on the Mogollon Rim in central Arizona, at approximately 2,180 m asl. The cave is formed in Permian age (270 mya) Kaibab Limestone, and is $1,585 \mathrm{~m}$ long. 


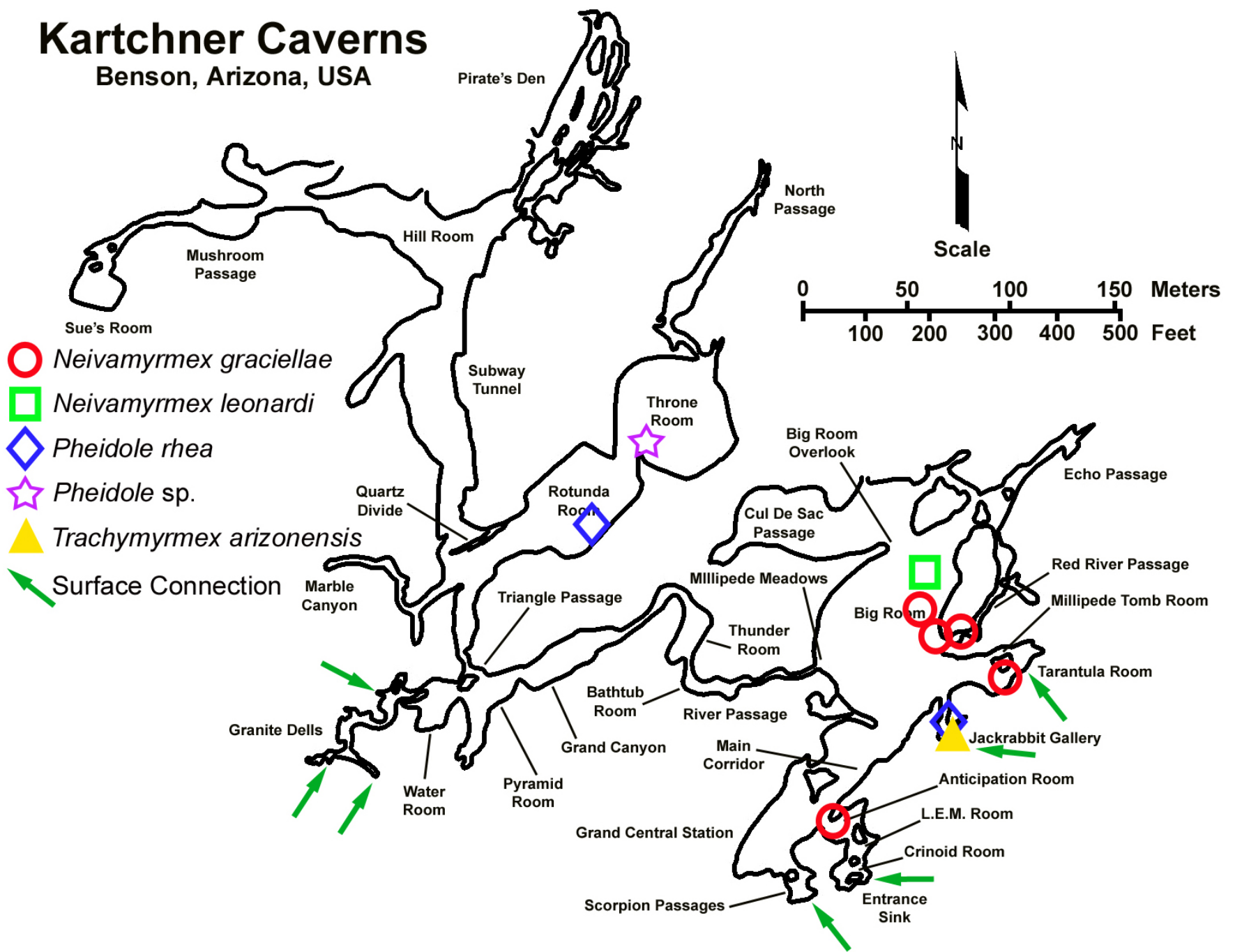

Fig. 1. Plan view map of Kartchner Caverns showing areas of the cave mentioned in this paper and locations where each ant species was documented. The records for the Throne Room (Pheidole sp.) and Rotunda Room (Pheidole rhea) were single individuals found along tour trails and are presumed to be vagrant occurrences. Arrows show known surface connections that are accessible to invertebrates.

- Patagonia Bat Cave is situated in Madrean Evergreen Woodland (Brown, 1982a) at 1,590 m asl near Patagonia, Arizona. The cave is formed in rock of igneous origin, and because of this is rather small, consisting of only two contiguous moderate-sized rooms (Fig. 2). The rear room serves as a seasonal roost for the lesser longnosed bat (Leptonycteris yerbabuenae Martinez \& Villa-R), a species currently listed as endangered under the United States Endangered Species Act (ESA). A few cave myotis also occupy the cave.

\section{PATAGONIA BAT CAVE}

Patagonia, Arizona

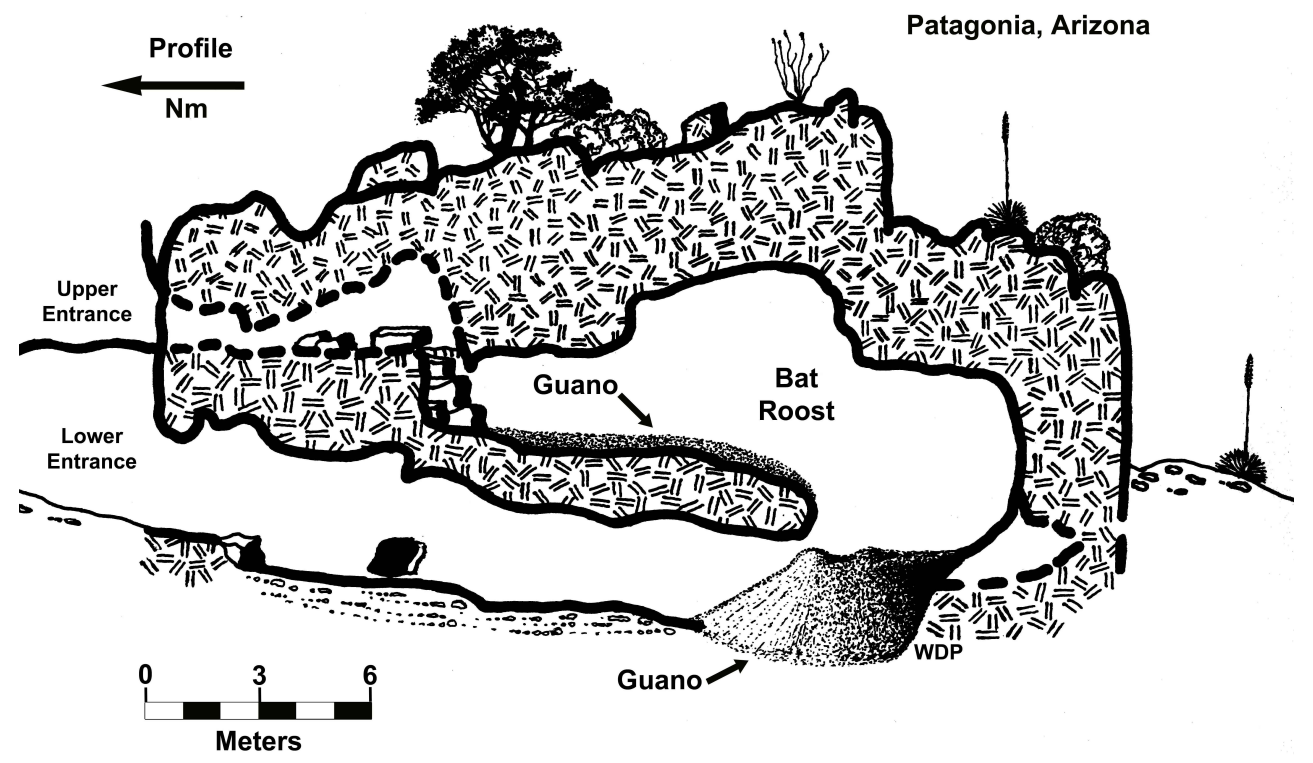

Fig. 2. Profile map of Patagonia Bat Cave near Patagonia, Arizona. 
- Nugget Cave is a small cave situated in Semidesert Grassland (Brown \& Makings, 2014) at an elevation of $1,500 \mathrm{~m}$ asl in the Santa Catalina Mountains north of Tucson, Arizona.

- Cathedral Cave is a limestone cave located near Ash Fork, Arizona in Great Basin Conifer Woodland (Brown, 1982b) at an elevation of 1,621 $\mathrm{m}$ asl (Shear et al., 2009).

Vertical subsurface depths reported for ant observations in the study caves were determined by surveying using Suunto brand hand held compass and clinometer, Leica DISTO ${ }^{\mathrm{TM}}$ lite $^{5}$ laser meter and a 100-foot Keson fiberglass tape. Survey data was reduced using Fountain Computer Product's 2003 version of Compass cave survey software.

Voucher specimens have been placed in the University of Arizona Insect Collection (UAIC), Tucson, Arizona.

Portions of these studies were conducted under an Arizona State Parks permit dated 10 September 2009 (Kartchner Caverns), and United States Forest Service Permits SUP0065, dated 5 April 1993, Extension dated 23 August 1995 and SUP0065-01, dated 30 April 2014.

\section{RESULTS}

\section{Literature review}

This paper is the first effort to consolidate records of ants from caves (Appendix A). The included data provides support for the discussion on the importance of these animals in cave ecology. Records of ants occurring in caves are numerous, dispersed among a variety of taxa, and include approximately 300 species in 80 genera (Wheeler, 1938; Wilson, 1962; Reddell \& Mitchell, 1971a, b; Decu et al., 1998; Reddell \& Cokendolpher, 2001; Framenau \& Thomas, 2008). The records are distributed globally, with the majority occurring in tropical regions or adjacent low latitudes (Appendix A). The list likely includes the great majority of available records, but it is probable that a few have eluded my search efforts.

Over half $(56 \%)$ of ant subfamilies and nearly one quarter $(24.4 \%)$ of currently valid genera have been recorded from caves (Appendix A). This broad representation across the family is evidence for a persistent presence of these animals in caves. It also speaks to the ubiquitous presence of ants globally, where they opportunistically occupy most available habitats. Hypogaeic species would intuitively be anticipated to occur more commonly in caves, but this is not evident in the available records. None of the genera appearing in the records are represented disproportionate to their species richness, and thus no affinity for cave use by any group is readily apparent. Since many of the records are ancillary, and not the result of targeted surveys for ants, attaching significance to any apparent prominence of a taxon among this data is problematic. Such analysis would require a review of all records of each species recorded from caves and is beyond the scope of this paper. Additionally, existing records are almost certainly clustered due to variability of search efforts regionally. Some regions have received focused attention, while others remain almost completely unstudied. This complicates any analysis using current records, and much additional data from antfocused research is needed before meaningful analyses can be performed.

Less than half of the records include an authorassigned ecological association (ecological group) for the ants with the caves where they were found. And, nearly half of the records providing an association are considered incidental (accidental) occurrences by the record author(s). Ants are thus seldom included in ecological discussions that accompany cave biological inventories. Since authors often fail to provide specific definitions to assigned ecological groups for reported occurrences (Sket, 2008), comparisons between records are problematic. A proliferation of classification systems for ecologically stratifying cave biota has, over the years, introduced considerable confusion into the biospeleological literature (Sket, 2008), and this further aggravates record comparisons. Thus, no effort has been made in this paper to adjust or correlate the record authors' intent for ecological categories they assigned.

\section{Field studies}

Observed nutrient resources in the studied caves varied significantly in quantity. Six of the caves have a long history of use by bats, and contain significant, annually refreshed bat guano deposits (Hoffmeister, 1986; Cockrum 1991; Cockrum \& Petryszyn, 1991; Mizutani et al. 1992; Buecher \& Sidner 1999; USFWS, 1995; Pape, 2014; Pape \& OConnor, 2014). However, ants were found in only two of these caves, and only at Patagonia Bat Cave were ants observed actively foraging at a bat guano deposit. Dead vertebrate and invertebrate remains contributed to overall nutrient resources in several of the studied caves. Ringtail scats (Bassariscus astutus Lichtenstein) are important nutrient sources for many cave invertebrates (Muchmore \& Pape, 1999; Pape, 2014; Pape \& OConnor, 2014), and were present in many of the caves in this study. Cave crickets and their guano are sometimes important nutrient sources in caves (Barr, 1967; Hubbell \& Norton, 1978; Muchmore \& Pape, 1999; Lavoie et al., 2007), particularly where cricket populations are significant, such as in Arkenstone Cave (Poulson, 1992; Muchmore \& Pape, 1999; Lavoie et al., 2007).

Plant materials found in the caves were generally quite limited, particularly in lower elevation desert caves, and were almost always concentrated near surface connections where such debris cascades into cave entrances. Only Porcupine Cave contained significant plant material in the cave interior. This cave occasionally takes a significant quantity of water directly into the entrance from the adjacent drainage during large hydrologic events, resulting in organic materials being transported into the cave. None of the studied caves contain a perennial vadose stream that provides a regular source of allochthonous nutrient input. However, a few of 
the caves occasionally receive small to moderate quantities of vadose flow that enters the caves through the alluvium of adjacent surface drainages during spring runoff or stochastic precipitation events. These waters are usually devoid of coarse organic materials, which are apparently filtered out during passage through the alluvium. The raw wood blocks used as bait in the Kartchner Caverns study did not attract any of the five ant species found in that cave.
Ants were recorded in six of the 35 caves studied. These new records increase the number of species recorded from Arizona caves from 10 to 20 species (Table 1). The distribution of these records is shown in Fig. 3. The following species accounts provide information on each of the ant records from Arizona caves, and assign an ecological group to the subject colony. The discussion section following the species accounts addresses how these findings support the importance of ants in cave ecology.

Table 1. Summary of ant species recorded from caves in Arizona and the ecological associations for observed colonies.

\begin{tabular}{|c|c|c|c|c|}
\hline Species & Cave Name & $\begin{array}{l}\text { Cave Entrance } \\
\text { Elevation (m) }\end{array}$ & $\begin{array}{l}\text { Ecological Group } \\
\text { (Source Author) }\end{array}$ & Source \\
\hline $\begin{array}{l}\text { Dorylinae } \\
\text { Neivamyrmex graciellae }\end{array}$ & Kartchner Caverns & 1,428 & Subtroglophile* & Pape \& OConnor, 2014 \\
\hline Neivamyrmex leonardi & Kartchner Caverns & 1,428 & Subtroglophile* & Pape \& OConnor, 2014 \\
\hline Neivamyrmex nigrescens & Arkenstone Cave & 1,112 & Trogloxene & This paper \\
\hline Neivamyrmex sp. & Arkenstone Cave & 1,112 & Subtroglophile & This paper \\
\hline$\frac{\text { Dolichoderinae }}{\text { Forelius keiferi }}$ & Arkenstone Cave & 1,112 & Trogloxene & This paper \\
\hline$\frac{\text { Formicinae }}{\text { Lasius arizonicus }}$ & Hidden Cave & 1,613 & Subtroglophile & This paper \\
\hline Lasius sitiens & Porcupine Cave & 2,140 & Subtroglophile? & This paper \\
\hline Nylanderia cf. hystrix & PARA 1801 & 3,540 & Incidental & Wynne \& Voyles, 2014 \\
\hline Camponotus ocreatus & Cathedral Cave & 1,621 & Unknown & Shear et al., 2009 \\
\hline Camponotus sp. & Hidden Cave & 1,613 & Incidental & This paper \\
\hline $\begin{array}{l}\text { Myrmicinae } \\
\text { Pheidole cf. porcula }\end{array}$ & Arkenstone Cave & 1,112 & Trogloxene & This paper \\
\hline Pheidole portalensis & Arkenstone Cave & 1,112 & Subtroglophile & This paper \\
\hline Pheidole rhea & Kartchner Caverns & 1,428 & Trogloxene & Pape \& OConnor, 2014 \\
\hline Pheidole rhea & Patagonia Bat Cave & 1,592 & Trogloxene & This paper \\
\hline Pheidole vistana & PARA 2602 & 736 & Incidental & Wynne \& Voyles, 2014 \\
\hline Pheidole sp. & Kartchner Caverns & 1,428 & Incidental $^{\dagger}$ & Pape \& OConnor, 2014 \\
\hline Pheidole sp. & PARA 2204 & 1,272 & Incidental & Wynne \& Voyles, 2014 \\
\hline Solenopsis aurea & Arkenstone Cave & 1,112 & Trogloxene? & This paper \\
\hline Solenopsis xyloni & PARA 2602 & 736 & Incidental & Wynne \& Voyles, 2014 \\
\hline Stenamma sp. & Nugget Cave & 1,518 & Trogloxene? & This paper \\
\hline Trachymyrmex arizonensis & Kartchner Caverns & 1,428 & Trogloxene & Pape \& OConnor, 2014 \\
\hline
\end{tabular}

*Originally listed as a troglophile in Pape \& OConnor, 2014.

'Originally listed as a trogloxene in Pape \& OConnor, 2014.

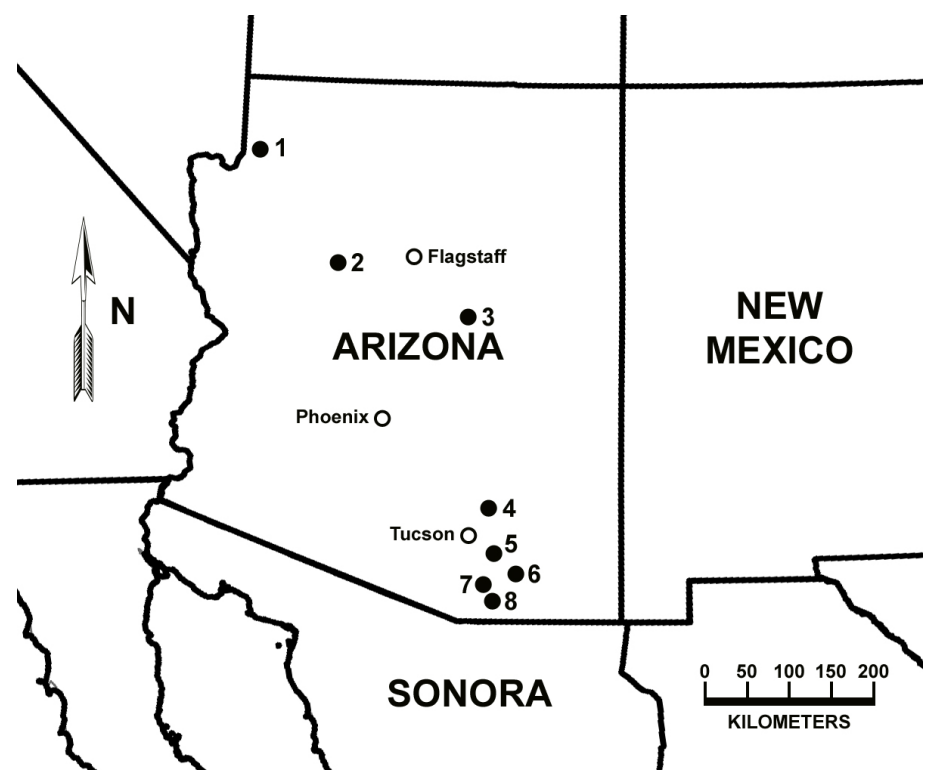

Fig. 3. Regional map showing location of caves discussed in this paper. 1) Grand Canyon-Parashant National Monument caves; 2) Cathedral

Cave; 3) Porcupine Cave; 4) Nugget Cave; 5) Arkenstone Cave;

6) Kartchner Caverns; 7) Hidden Cave; 8) Patagonia Bat Cave.

\section{Species accounts}

Neivamyrmex graciellae

Neivamyrmex graciellae Mann was previously known only from the states of Jalisco and Oaxaca in central and southern Mexico, and from a single occurrence in southern Arizona at Florida Canyon, on the west flank of the Santa Rita Mountains (Snelling \& Snelling, 2007). A recent study at Kartchner Caverns revealed a long-term presence of this species associated with that cave (Pape \& OConnor, 2014). N. graciellae has been observed active in the cave at depths ranging from 15 to $24 \mathrm{~m}$ below the surface.

During an earlier study at KCSP Welbourn (1999) reported the presence of what appeared to be old ant trails in the soil substrate (Fig. 4) near the entrance to the Red River Passage (Fig. 1). However, no ants were observed associated with the trails, or anywhere else in the cave during his study. Subsequent to Welbourn's study and commercial development of the cave as a state park, KCSP personnel had observed and sampled ants in the cave on several occasions. My review of these materials revealed the presence of 
two army ant species; N. graciellae and Neivamyrmex leonardi Wheeler.

During the recent study we found contemporary evidence of ant trail building in the same area of the cave that Welbourn mentioned (Figs. 5 \& 6). One of the trails (Fig. 5A) entered an access turret (Fig. 5B) atop a mud-covered calcite bridge that spans the Red River Passage in the cave. It is presumed that this natural bridge structure contained a bivouac of $N$. graciellae at one time. There are very few records of ant trails found in caves. The ant trails in Kartchner Caverns are similar to those of Labidus coecus Latreille, which have rarely been reported in caves in Texas and Mexico (Fig. 8 in Reddell \& Cokendolpher, 2001). There are currently no Arizona records for $L$. coecus. Nomamyrmex (N. esenbecki wilsoni Santschi), a deep subterranean doryline (Schneirla, 1971), has been recorded in the United States only from south central Texas (Watkins, 1985), and has so far not been recorded in caves.

A raiding column of $N$. graciellae was observed in the Red River Passage on 3 October 2013. Hundreds of ants, consisting of both minor and major workers, were moving in both directions along the approximately

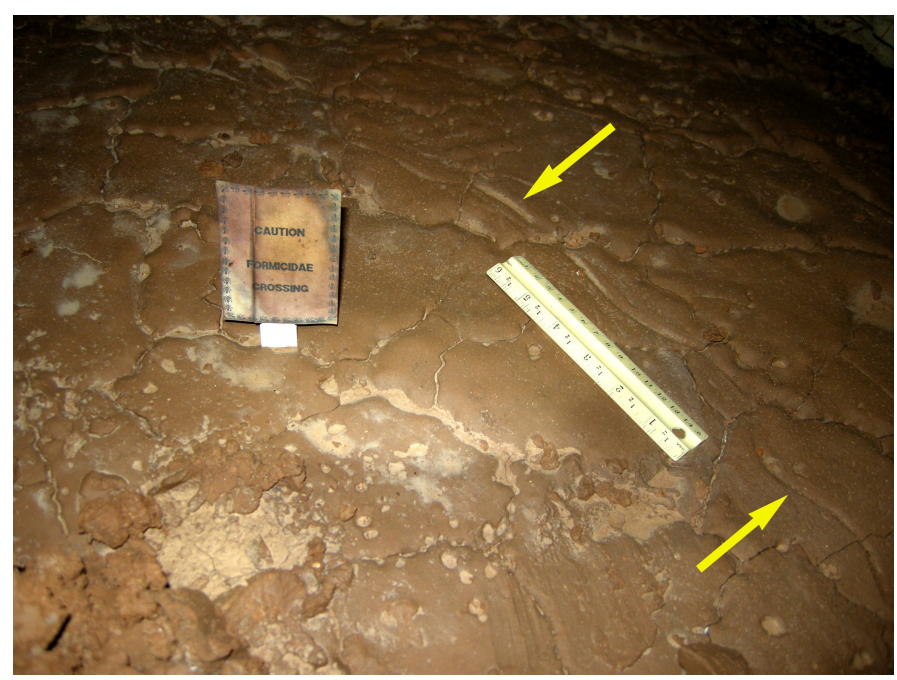

Fig. 4. Old, eroded army ant trail (arrows) in cave mud substrate near the entrance to the Red River Passage in Kartchner Caverns. The scale is $15 \mathrm{~cm}$. The sign is from the original study conducted in the cave (Welbourn, 1999), and reads Caution - Formicidae Crossing.

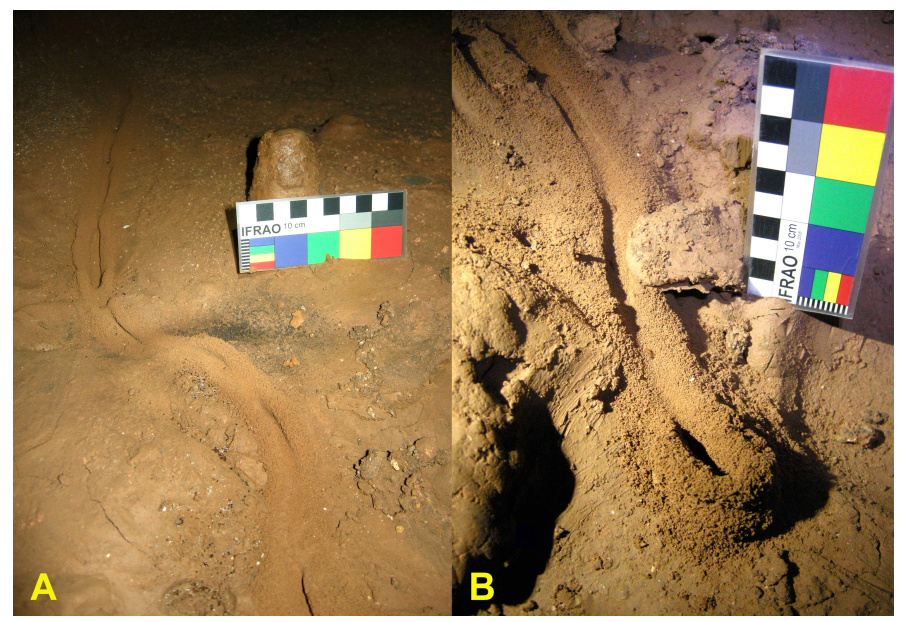

Fig. 5. Recent army ant trail in the Red River Passage at Kartchner Caverns (A), which leads to the old bivouac access turret, situated atop a mud-covered calcite bridge that spans the ephemeral Red River Passage stream (B). The scale is $10 \mathrm{~cm}$.

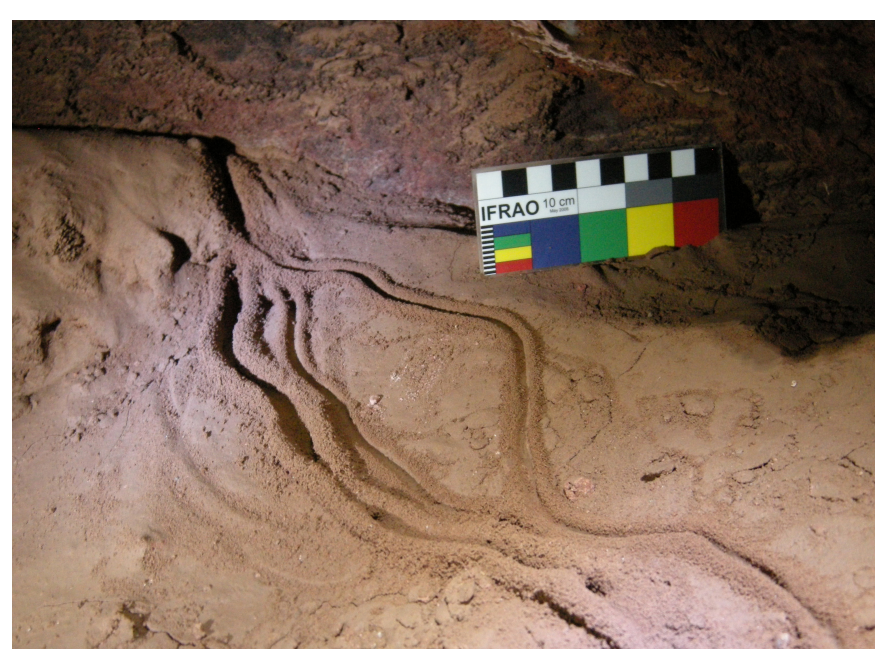

Fig. 6. Multiple recent, parallel trails of Neivamyrmex graciellae in the Red River Passage at Kartchner Caverns. The right trail cross-cuts the previous trails at the top of the image. Scale is $10 \mathrm{~cm}$.

$11 \mathrm{~m}$ of their trail that was visible. The ants were transporting prey, including pupae and workers of Crematogaster opuntiae Buren (Fig. 7). They entered the old bivouac site via the turret but emerged from the far side of the bridge and continued to the northeast. The old bivouac site was apparently not actively being used at the time. Two meters beyond the turret the column went beneath the east wall of the passage at the contact of the bedrock with the floor soil fill. The southwest arm of their trail entered a humanly inaccessible area of breakdown blocks on the cave floor. Small numbers of $N$. graciellae are occasionally observed in other areas of the cave by park staff or researchers.

An old waste midden consisting of hundreds of undigestible cuticular elements of C. opuntiae (Fig. 8) was found immediately adjacent to the raiding column trail, four meters southwest of the calcite bridge access turret. The midden is presumed to be the remains of an old $N$. graciellae bivouac site, where the undigestible parts were dropped out of the bivouac. The only other army ant bivouac records from caves are of $L$. coecus, found in at least three caves in Texas, including: Beck Crevice Cave, Beck Sewer Cave and Testudo Tube (Reddell \& Cokendolpher, 2001).

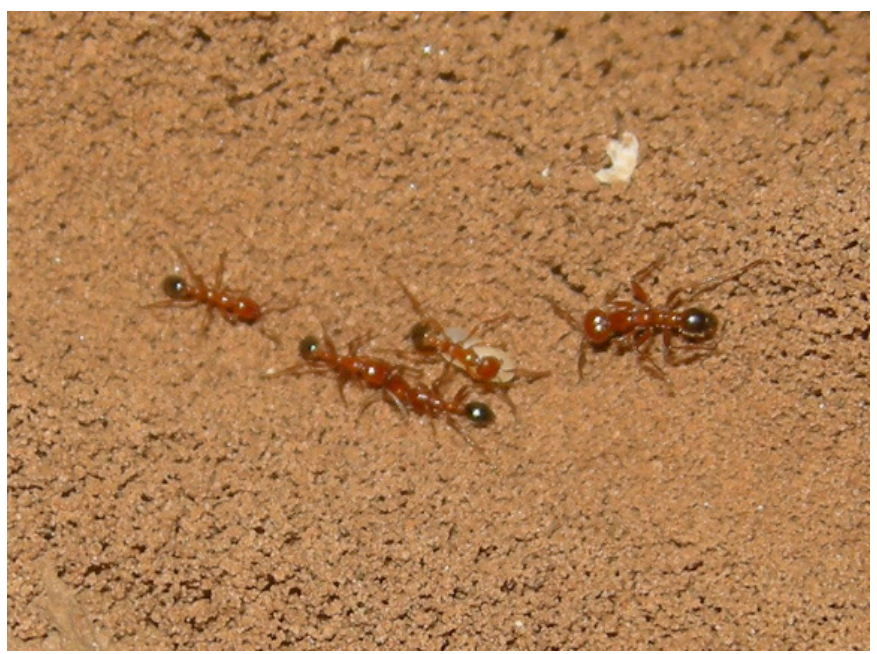

Fig. 7. Minor workers of Neivamyrmex graciellae on their raiding trail in Kartchner Caverns, October 3, 2013. The ant at the center of the image is carrying a Crematogaster opuntiae pupa. 


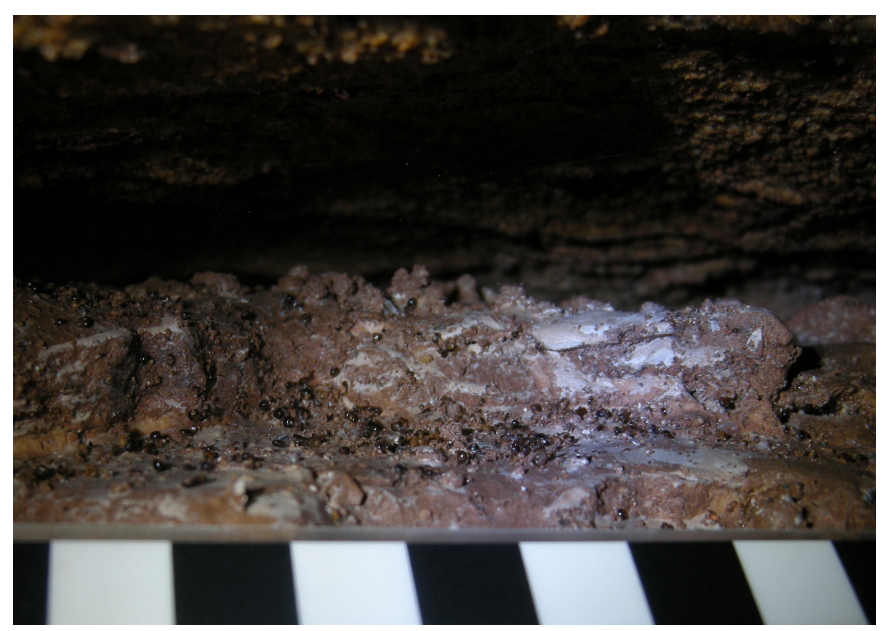

Fig. 8. Remains of Crematogaster opuntiae prey in the waste midden at the Red River Passage in Kartchner Caverns. The midden was likely associated with a previous Neivamyrmex graciellae bivouac.

It is not known whether $N$. graciellae feeds exclusively on ants, or may opportunistically prey on other arthropods in the cave, including those associated with the bat guano deposits. The absence of ant trails in the vicinity of the guano deposits suggests that $N$. graciellae does not forage at those sites.

Welbourn (1999) reported that some of the ant trails he observed were constructed over human footprints in the cave. Since the cave was not discovered until 1974, those trails would have been no older than 17 years in age at the time of his study (1989-1991). The old trails are still visible today (Fig. 4), and are now between 27 and 42 years in age. The old trails are approximately $1.5 \mathrm{~m}$ above the current hydrologic flow level of the ephemeral stream in the adjacent Red River Passage, and are unlikely to have been affected by flowing or pooled water. The degeneration of the trails probably results from a gradual equalization slumping of the clay soil substrate due to repeated changes in soil moisture content. Repeated expansion and contraction of the soil over long periods of time would gradually obliterate the trails. Entrenched ant trails have so far been found only in the vicinity of the Red River Passage.

C. opuntiae, has not been found in the cave, and is considered unlikely to occur there. $N$. graciellae probably leaves the cave to forage, and likely also during alate dispersal. Neither active bivouacs nor reproductives of $N$. graciellae have been observed in the cave, but the presence of the old bivouac access turret, the waste midden, active prey transport and multiple trails of varying age are ample evidence supporting a long-term use of the cave by this species. Based on this evidence $N$. graciellae is considered a subtroglophile in Kartchner Caverns.

\section{Neivamyrmex leonardi}

$N$. leonardi is a small, pale-yellow, eyeless army ant, for which there were previously only two Arizona records, one each, from Nogales and Tucson (Snelling \& Snelling, 2007). The species is also known from Oklahoma, Texas, Nevada and California in the U.S., and from Baja California and northern Baja California Sur, Mexico (Cokendolpher, 1990; Snelling \& Snelling, no date; 2007), with the majority of records from southern California (Snelling \& Snelling, 2007). There are no previous cave records for the species.

There is currently only a single record of this species from Kartchner Caverns, from 19 December 2006, when one major and three minor workers were sampled (Pape \& OConnor, 2014). The ants were found obtaining water from a leaking faucet along a tour trail deep within the cave near one of the main bat guano deposits in the Big Room (Fig. 1). It is not known whether $N$. leonardi may forage at the nearby bat guano deposit, but none of the ants were observed there during numerous visits to the location during the recent two-year study (Pape \& OConnor, 2014). Bat guano samples taken monthly at this location during that study did not include any of the ants, and the species is apparently rare in the cave. $N$. leonardi is certainly a subtroglophile in the cave. The potential for the colony being eutroglophilic is reviewed in the discussion section.

\section{Neivamyrmex nigrescens}

While performing field observations at the entrance to Arkenstone Cave on 12 November 2000, I observed a small leader column of several $N$. nigrescens exiting the cave beginning at 10:26 hrs. About two-dozen ants were in the column, going upslope a distance of about $20 \mathrm{~cm}$. They remained in the shade beneath a shallow overhang of the bedrock fault along which the cave is developed, and did not venture beyond the point where the bedrock was visibly damp. The ants appeared to want to continue further from the cave, but were apparently discouraged by daylight and/or moisture conditions (surface dryness) they encountered, and periodically returned to the cave. The rock surface temperature was $8^{\circ} \mathrm{C}$ in the shade of the cave entrance sink at the time. The area the ants were traversing was approximately $0.9 \mathrm{~m}$ from the sun-shade interface at the north side of the cave entrance sink. The ants were intermittently active here between 10:26 and 14:10, a total of just over three hours. No prey was observed being transported along this short, exploratory column. Based on current knowledge, this colony is considered a trogloxene in the cave.

\section{Neivamyrmex sp.}

During a visit to Arkenstone Cave on 23 October 1999 a raiding column of Neivamyrmex sp. was observed actively foraging in the cave. The ants were first observed in the First Antechamber, which is just within the cave aphotic zone (Fig. 9). This location is $33 \mathrm{~m}$ from the cave entrance and 36 meters vertically below the surface of the cave hill.

The leading edge of the foraging column was somewhat dispersed. About two meters closer to the front of the cave, where the ants were more numerous, they had scavenged a tachinid fly and were transporting it back along the column in two pieces consisting of its left wing and the co-joined thorax and abdomen. The ant column was traced back towards the front of the cave where they were observed entering the cave directly from the epikarst into a breakdown-choked area approximately seven 


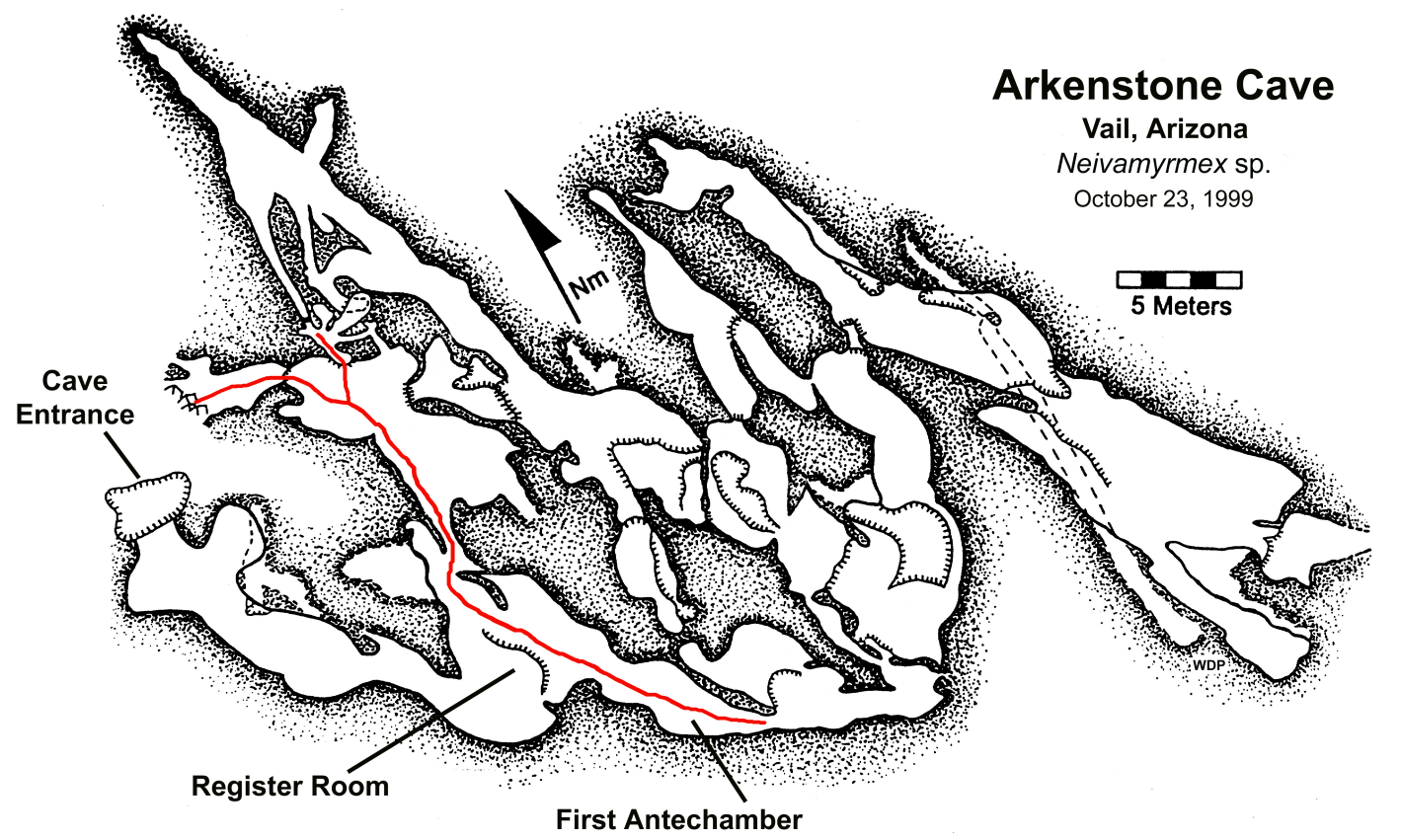

Observed foraging route of
Neivamyrmex sp. on October 23,1999

Fig. 9. Plan view map of Arkenstone Cave showing foraging route of Neivamyrmex sp. observed on October 23, 1999.

meters east of the gated human entrance. From this point the ants had a single column, which was observed to divide only once. The left branch headed up a parallel passage a distance of at least two meters. The main foraging column extended for a distance of $24 \mathrm{~m}$ through the Register Room and into the adjacent First Antechamber (Fig. 9, red line). The linear extent of the column observed within the cave was approximately $34 \mathrm{~m}$. The foraging ants averaged about 60 per decimeter along the column, resulting in an estimated 20,000 observed individuals.

Along the length of the column several invertebrates had been attacked by the ants, including two adult cave cricket (Ceuthophilus cf. pinalensis Hubbell: Rhaphidophoridae) (Fig. 10). Due to their large size, the crickets had not been moved along the column, but were being processed by the ants into smaller pieces for easier transport. The crickets had evidently been taken down where they stood when they were overcome by the advancing ant column. Several cave millipedes Colactis utorum Chamberlin (Diplopoda: Dorypetalidae) had also been subdued by the ants (Fig. 11). The millipedes are not highly mobile and were easily overcome by the advancing ant column.

This occurrence of Neivamyrmex sp. in Arkenstone Cave was the only time that the species was observed during more than 130 visits (including the 124 visits that had a biological survey component) to the cave between October 1987 and September of 2002. This is the first instance reporting an army ant colony preying on cave animals. Neivamyrmex sp. is a subtroglophile in the cave.

\section{Forelius keiferi}

Forelius keiferi Wheeler was observed entering and leaving Arkenstone Cave on 16 April 2013. Five ants were seen removing a small, round piece of debris from the cave, which may have been a piece of a ringtail scat. The species is a trogloxene that forages in the cave entrance area.

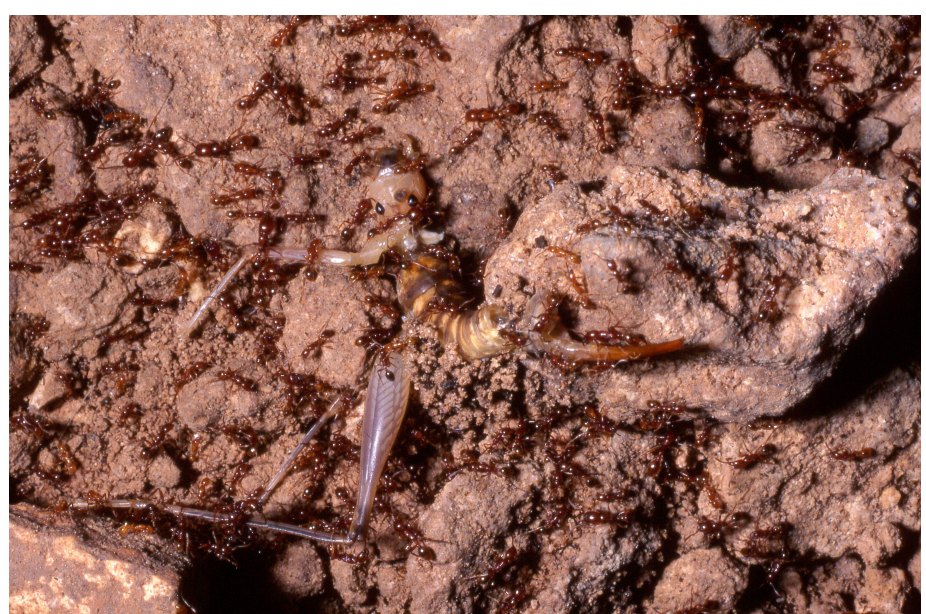

Fig. 10. Raiding column of Neivamyrmex sp. dismembering a live-captured adult female cave cricket (Ceuthophilus cf. pinalensis) in Arkenstone Cave, October 23, 1999.

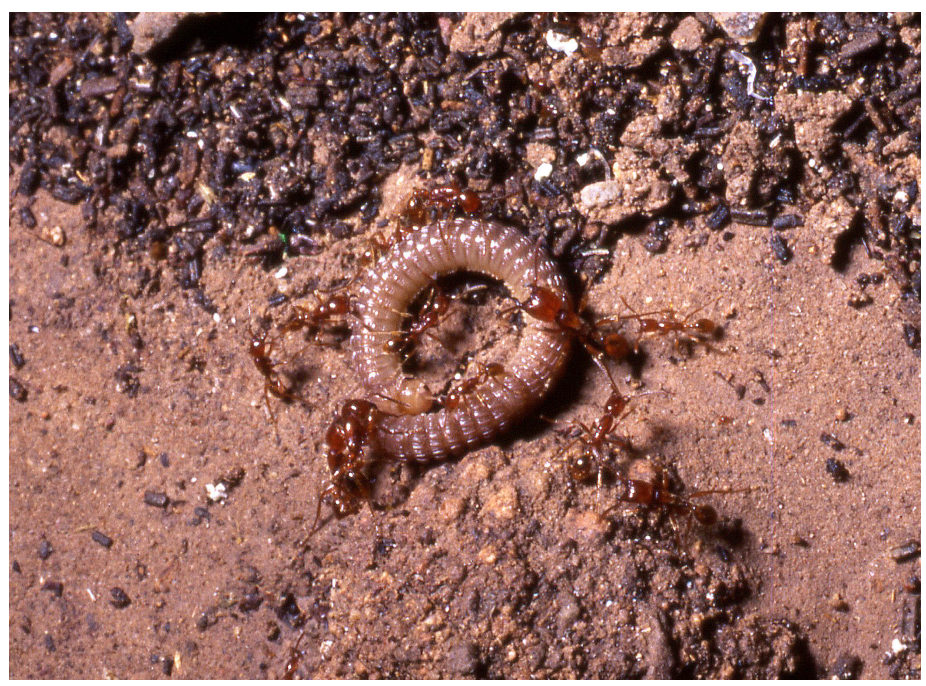

Fig. 11. Raiding column of Neivamyrmex sp. attacking a dorypetalid millipede (Colactis utorum) in Arkenstone Cave, October 23, 1999. 


\section{Lasius arizonicus}

During a visit to Hidden Cave on 11 January 2013 a single ant nest access soil turret and an adjacent tunnel surface breach were observed on the cave floor $30 \mathrm{~m}$ from the cave entrance. No ants were present at the time of this visit. Several subsequent visits to the cave revealed additional digging activity of the ants in the front part of the cave, but the ants (Lasius arizonicus Wheeler) were not found and sampled until 27 June 2015. During this visit two colonies of $L$. arizonicus were found active in the cave. Approximately a dozen ants were roaming over the cave floor and beneath debris in proximity to their nest in the front part of the cave, in the area where their diggings had previously been observed. An abundance of white fungus is present on fine plant rootlets in the soil substrate where the ants occur in this area. It is not known if the fungus is significant in the ecology of the species. A second colony was found at the very back of the cave. Here, a small cluster of approximately 20 individuals were assembled in a concentrated group on the floor of the cave. A nest entrance was not evident in the soft floor sediments at this location. Due to the nesting activity and persistent use of Hidden Cave by $L$. arizonicus, the colonies occurring in the cave are assigned the status of a subtroglophile.

\section{Lasius sitiens}

A few workers of Lasius sitiens Wilson were found in the front part of Porcupine Cave in northern Arizona on 15 May 1999, approximately $6 \mathrm{~m}$ in from the cave entrance. The association of this colony with the cave was not readily apparent, but Wilson (1955) made the following comments regarding this species: "The light coloration, small eyes, and shortened appendages of sitiens constitute a remarkable morphological convergence to the species of the subgenus Cautolasius, and specifically to the primitive species $L$. (C.) alienoflavus Bingham. There can be little question that the characters shared by these two species are the mark of a subterranean mode of life." The cave is subject to occasional flooding during significant precipitation events. The presence of organic materials adhered to the ceiling in the interior of the cave indicates that the cave totally fills with water on occasion. The colony of $L$. sitiens in Porcupine Cave may be subtroglophilic.

\section{Nylanderia (Paratrechina) cf. hystrix}

There is a single record of this species from a cave (PARA 1801) in the Grand Canyon-Parashant National Monument in northern Arizona. The cave is located at an elevation of $3,540 \mathrm{~m}$. The occurrence was considered incidental (accidental) by the authors. Ants for all the PARA cave records included in this paper were taken in baited pitfall traps in the cave entrances (Wynne \& Voyles, 2014). There is only one previous record of $N$. hystrix from Arizona, collected in 2003 from beneath a stone in a desert wash at Matkatamiba Canyon in Grand Canyon National Park (AntWeb). The Matkatamiba Canyon specimens are archived in the collection at the California Academy of Sciences (CASENT 0056873).

\section{Camponotus ocreatus}

This species is recorded from Cathedral Cave in northern Yavapai County, Arizona (Shear et al., 2009). The Shear paper addressed new cave millipede species from the southwestern United States, and there was no ecological information specific to $C$. ocreatus included in the work, thus its ecological status is unknown.

\section{Camponotus sp.}

During a visit to Hidden Cave on 7 January, 2015 a single Camponotus sp. major was found approximately $30 \mathrm{~m}$ into the cave. This individual was alive, but mostly immobile, and barely able to stand. It is assumed that this individual is an isolated, vagrant from the surface that could not find its way out of the cave. Regular human traffic in the cave may easily have obliterated its chemical trail, causing the animal to become lost in the cave. This species is not C. ocreatus. This record is considered an incidental occurrence in the cave.

\section{Pheidole cf. porcula}

This small, uniformly brownish-yellow ant has a fairly regular presence within Arkenstone Cave, where they forage on nutrients in the twilight zone. Unfortunately only minors have ever been found. This species was incorrectly reported as Monomorium sp. in Muchmore and Pape (1999). This ant seems most similar to Pheidole porcula Wheeler, but may be an undescribed species. The species has been found no deeper than $27 \mathrm{~m}$ from the entrance, and they rarely enter the aphotic zone. They have been observed in the cave during most months of the year, with seldom more than a couple dozen foraging individuals present at any given time.

They have been observed scavenging a variety of dead invertebrates from the cave, including a lithobiid centipede, an epigean grasshopper (Phrynotettix tshivavensis Haldeman) and cave crickets (C. cf. pinalensis). They dismember larger carcasses, and cooperatively remove pieces from the cave to their nest outside the cave (Fig. 12). A large number (50-75) of the ants were observed scavenging at ringtail urine on the floor of the Register Room. The species is a trogloxene in Arkenstone cave.

\section{Pheidole portalensis}

Pheidole portalensis Wilson was recorded from Arkenstone Cave on 16 November 2003, when at least ten ants were seen foraging from the cave entrance. One ant was carrying the abdomen of a small beetle (Hyporhagus sp.; Zopheridae) into the cave. The ants did not go any further than about $30 \mathrm{~cm}$ outside the cave, and it is presumed that their nest was in the front portion, and not deep within the cave. According to Stefan Cover (as cited in Wilson, 2003), P. portalensis regularly nests in cracks in rock walls, from which they forage. In this instance apparently, the ants selected a cave for their nest site. This colony is assigned a subtroglophile status based on the presence of their nest within the cave. 


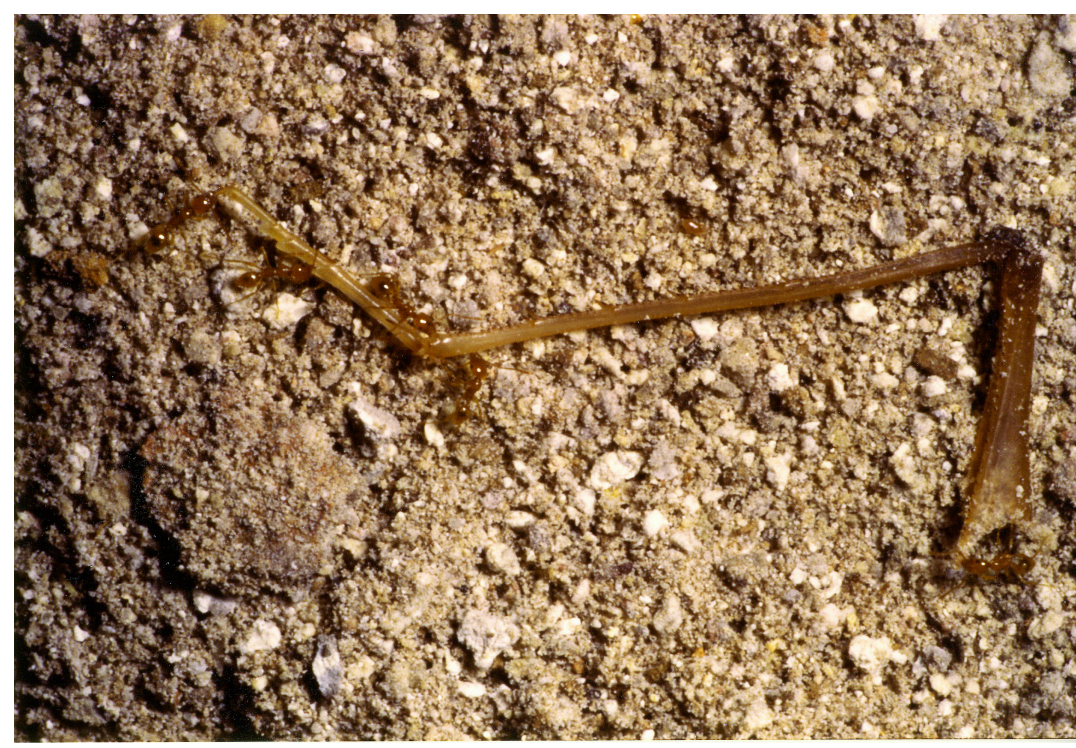

Fig. 12. Several Pheidole cf. porcula inside Arkenstone Cave transporting a leg of Ceuthophilus cf. pinalensis out of the cave, July 19, 1992.

\section{Pheidole rhea}

P. rhea was occasionally found in Kartchner Caverns during the recently completed two-year study (Pape \& OConnor, 2014). They were usually found in the Jackrabbit Shaft and the adjacent portion of the Jackrabbit Gallery (Fig. 1). There is one additional record of the species taken from a tour trail curb deeper in the cave, in the Rotunda Room. This latter record likely represents a vagrant animal, which may have been transported deep into the cave on a tour visitor. $P$. rhea is relatively common on the hill above the cave.

There is evidence that $P$. rhea in Kartchner Caverns is occasionally preyed upon by the endemic thread-legged bug Phasmatocoris labyrinthicus Pape (Pape, 2013). Three ants, including one major, were found lying dead on the cave floor in the Jackrabbit Gallery near the Jackrabbit Shaft door below where the predatory thread-legged bugs have been found on several occasions. We do not know why this ant species comes into the cave. Their presence could be a simple case of proximity to a nest in the soil horizon near the top of the Jackrabbit Shaft. A variety of invertebrates occur in this area of the cave, and $P$. rhea could possibly be preying on some of these species, although this has not been observed. Due to its somewhat regular presence and a suspected nexus with the ecology of the cave, the $P$. rhea colony at Kartchner Caverns is presumed to be a trogloxene.

A second $P$. rhea colony was observed at Patagonia Bat Cave in southern Arizona on 17 August 1996. The ants accessed the cave through the lower entrance, and a steady column of minor workers was busily removing arthropods and other materials from the main bat guano deposit at the rear of the cave (Fig. 2). Among the prey were larvae of a dermestid beetle (Dermestes carnivorous Fabricius; Fig. 13; arrow 1) and two species of bat flies (Diptera: Streblidae); Trichobius major Coquillett (Fig. 13; arrow 2) and $T$. sphaeronotus Jobling. Live bat flies are highly unlikely to occur on the guano deposit on the floor of the cave. Possibly the ants were retrieving flies that had died of natural causes, or that may have been injured or killed by grooming bats. Flies dispatched in this manner would fall to the guano deposit where they could be scavenged by the ants. Because Pheidole commonly forage on the ground, and seldom climb very high in vegetation even when harvesting seed (Wilson, 2003), it seems improbable that the ants would capture live flies since they would have to forage on the cave ceiling where the flies typically occur in the bat roost.

Leptonycteris primarily feed on nectar and pollen of cacti and agaves during nocturnal foraging forays, and return to the roost to digest their meal and groom. Pollen in their guano, combined with remnants groomed from their faces, accumulates below the roost into a thin, consolidated yellow cake. The ants were seen removing rather large pieces of this material from the cave. The ants were also removing cactus fruit seeds from the bat guano deposit. These were identified as seeds of the organpipe cactus (Stenocereus thurberi Engelmann) by W.D. Peachey (personal communication, 24 October 2013). The site was revisited on 30 August 2014 but no ants were found foraging in the cave. The nearest Pheidole nest located during this second visit was approximately $235 \mathrm{~m}$ south of the cave. The $P$. rhea colony documented foraging in the cave is assigned the status of a trogloxene.

\section{Pheidole vistana}

Three $P$. vistana were sampled in the entrance area of a cave (PARA 2602) in the Grand CanyonParashant National Monument in northern Arizona by Wynne \& Voyles (2014). The cave is located at an elevation of $736 \mathrm{~m}$. This occurrence of $P$. vistana in the cave was considered incidental (accidental) by the authors.

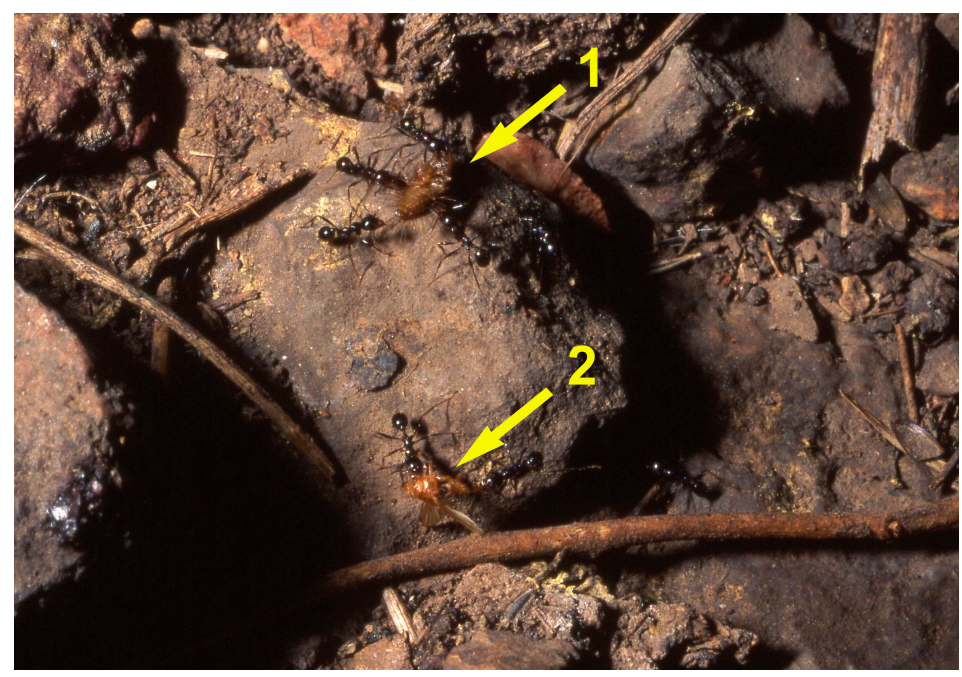

Fig. 13. Foraging Pheidole rhea in Patagonia Bat Cave, 16 August 1996. Prey include larvae of the dermestid beetle Dermestes carnivorous (arrow 1) and the streblid fly Trichobius major (arrow 2). Faint, yellow pollen guano splatters of the lesser long-nosed bats (Leptonycteris yerbabuenae) that occupy the cave can be seen on the rock in the upper left portion of the photograph. 
Pheidole sp.

A single minor of this species was found on 27 May, 2007 in the Throne Room, deep within Kartchner Caverns. However, because there is only this single record, and the sample location was on the tour trail, this individual is most likely an incidental that came into the cave with one of the commercial tours.

\section{Pheidole sp.}

A single unidentifiable minor worker of this species was taken in the entrance to PARA cave 2204 (Wynne $\&$ Voyles, 2014). This species was considered an incidental (accidental) by the authors.

\section{Solenopsis aurea}

At least one species of Solenopsis (the invasive S. invicta) is known to forage within caves (Elliott, 1992, 2000; Longacre, 2000; Taylor et al., 2005; Cokendolpher et al., 2009). A single worker of the desert fire ant (Solenopsis aurea Wheeler) was found just inside the entrance to Arkenstone Cave on 14 January 2012. The ants could potentially prey on invertebrates that occupy the cave. The association of this species with the cave is not known, but it is a presumed trogloxene.

\section{Solenopsis xyloni}

Five S. xyloni were taken in the entrance of PARA cave 2602 (Wynne \& Voyles, 2014). The ants were considered incidentals (accidentals) by the authors. As the numbers of an ant species found in an individual cave increases, either at one time, or cumulatively during separate events, there is an implied greater potential that their presence has some ecological significance. Normally, the presence of five ants would suggest foraging behavior within the cave. However, since the ants were taken in baited traps this confounds the question, since the ants may have been attracted to the bait from outside of the cave. This record should continue to be considered incidental until further evidence suggests otherwise.

\section{Stenamma sp.}

Three Stenamma were sampled at Nugget Cave in the Santa Catalina Mountains north of Tucson on 21 July 1993. Unfortunately the specimens have been lost, and had not been identified to species. An attempt to relocate this species at Nugget Cave was made on 17 August 2014, but the ants were not present at that time. The association of this colony with the cave is suspected to be that of a trogloxene.

\section{Trachymyrmex arizonensis}

T. arizonensis was recorded from Kartchner Caverns during the recent two-year macro-invertebrate study of the cave (Pape \& OConnor, 2014). Most observations of the species were in the Jackrabbit Shaft (Jackrabbit Gallery area; Fig. 1). The ants were observed moving chaff from their fungus garden to a refuse midden near the top of the shaft. The chaff had overflowed this repository and had cascaded down into the shaft. The fungus garden was not visible, but was likely present immediately adjacent to the shaft in a fracture in the pediment, or in the adjacent soil profile.

During a visit to the cave on 31 May 2012 the species was observed excavating a nest in a crack in the bedrock wall about $2.5 \mathrm{~m}$. below the top of the shaft. There were about two dozen ants actively working the hole and removing soil particles. A soil spoils pile had accumulated on part of the metal framework for the shaft ladder structure. This nest was still active two years later, on 19 October 2014.

Army ants (Neivamyrmex spp.), many of which are primarily ant predators, have been recorded preying on $T$. arizonensis in southern Arizona (LaPolla et al., 2002; Rabeling et al., 2007). Neivamyrmex have not been found in proximity to the Jackrabbit Shaft. If $N$. graciellae does prey on $T$. arizonensis, this likely occurs outside the cave, in the epikarst or the overlying soil profile. $N$. leonardi is probably too small a species to successfully predate Trachymyrmex spp., and the single record for the species is deep within the cave, far from where $T$. arizonensis has been found.

The presence of $T$. arizonensis in the cave is opportunistic in that they have incorporated this small portion of the cave as a part of their occupied habitat. Since their nest is not technically within the cave and the ants forage outside the cave, this colony of $T$. arizonensis is assigned the status of a trogloxene.

\section{DISCUSSION}

There are currently over 13,000 recognized species of ants (Formicidae) in the World, possibly representing only about one half to one third of the actual number of extant species (Bolton, 2014; Ward, 2014). Considering their impressive species diversity, global distribution, and integration into nearly every terrestrial ecotope, it seems intuitive that ants should have a significant presence in the ecology of caves.

Obstacles to recognition of the role that ants play in cave ecology have included: the apparently low level or relative infrequency of their presence in these environments; the fact that many cave biological studies are limited in extent; and an apparent misalignment of the presence of observers with the peak activity periods of ants in caves. That is, researchers commonly visit caves during daylight hours, due to convenience, and may miss crepuscular or nocturnal ant activity, particularly some of the subterranean species, such as Neivamyrmex. Additionally, perceptions of what constitutes "typical" behavior for a given ant species should not preclude recognition of individual colony behavior associated with use of cave nutrients.

The number of ant species recorded in individual caves was to a great extent a function of search effort expended. Six ant species were recorded from Arkenstone Cave, where cumulative search time was approximately 500 hours over 14 years. The five species of ants found in Kartchner Caverns were documented during 210 hours of searching during a two-year study (Pape \& OConnor, 2014). Search efforts in the remaining caves were considerably less intense, often involving only a few hours during 
a single visit. Only one of the caves (Hidden Cave) yielded more than a single ant species (two), one of which was considered an incidental occurrence. No ants were found in 29 of the study caves. Since ants seem to have a low level and sporadic, but persistent presence in caves, their detection may require extensive searching. Thus the negative findings from the low-effort sites are inconclusive, and the apparent absence of ants in these caves in no way precludes their use of those sites.

Observations of cave invertebrates in Arizona have revealed a low level and sporadic, but persistent use of cave habitats and their contained resources by ants. That is, an ant species may be present in a cave irregularly or occasionally (sporadic), and yet is persistent over time, with repeated occurrences separated by months or years. The importance of ants in cave ecology is supported, in part, by observations of colonies of 13 ant species exploiting resources in Arizona caves (this paper). The majority of these observations are from two caves in southeast Arizona, Kartchner Caverns and Arkenstone Cave, which have been extensively studied. It is assumed that similar use of cave resources by ants occurs elsewhere, particularly in the lowland humid tropics where ants have a more pronounced presence, and where nutrients are generally more available in both epigean and hypogean environments (Romero, 2009, 2011). This is supported by the numerous records of ants reported from caves in these regions (Appendix A).

\section{Subterranean terrestrial habitats}

Subterranean terrestrial habitats have in common their humid, aphotic environments and spatial proximity. Subterranean profiles in karst regions typically include the following habitats, from top to bottom: soil, epikarst, bedrock fissures, and caves (Juberthie, 1980; Camacho, 1992; Juberthie, 2000; Culver \& Pipan, 2014). Each of these habitats supports its own unique biota (Howarth, 1983; Camacho, 1992; Culver \& Pipan, 2009a, 2014), but due to proximity and microclimatic similarity there is much biotic movement across their boundaries (Howarth, 1983; Culver \& Pipan, 2014; Pape, personal observation). Cave entrances serve as movement corridors that are readily accessible to animals occupying both epigean and subterranean habitats (Howarth, 1983; Romero, 2009; Prous et al., 2015; Pape, personal observation). Thus, caves are often intimately connected with habitats occupied by edaphic ant species, and nutrients present in caves are commonly within the foraging range of their colonies.

\section{Nutrients in caves}

Caves have long been recognized as comparatively oligotrophic environments, with most nutrients being transported into caves from photic epigean ecosystems by hydrologic movement, gravity or animal transport (Camacho, 1992; Polis et al., 1997; Culver \& Pipan, 2009a; Romero, 2009; Pape \& OConnor, 2014; Prous et al., 2015). Bacteria and fungi are important decomposers of organic materials in caves, and the role of bacteria and archaea in chemolithoautotrophic primary production in these environments is only beginning to be understood and appreciated (Cunningham et al., 1995; Ortiz et al., 2013). Nutrient sources commonly found in caves include plant debris, small vertebrates, macroinvertebrates, animal carcasses, and feces (Howarth, 1983; Ferreira \& Martins, 1999; Hüppop, 2000; Culver \& Pipan, 2009; Trajano \& Bichuette, 2009; Prous et al., 2015; Pape, personal observation). Bat and bird guano deposits in caves are occasionally extensive, and often support their own diverse invertebrate fauna (Ferreira \& Martins, 1999; Deharveng \& Bedos, 2000; Moulds, 2004; 2006; Ferreira et al., 2007; Pape, 2014; Pape \& OConnor, 2014). Animals, including ants, forage at these guano deposits, where they scavenge materials and/or prey on invertebrates integral to the guano food web. The guano of caveroosting frugivorous bats commonly includes the seeds of fruits on which they feed, and may be gathered by seed harvesting ants, such as Messor, Monomorium, Pheidole, Pogonomyrmex, and others. So it is not only scavenging and predatory ants that forage at cave guano deposits, but seed harvesting species may also be present. The Oil Bird (Steatornis caripensis Humboldt), or Guacharo, nests in caves in northern South America and the Caribbean region. Oil Birds are also frugivorous and regurgitate fruit parts, including seeds, from their diet in their nesting caves (Polis et al., 1997; Holland et al., 2009; Romero, 2009). The seeds of fruits consumed by Oil Birds are too large to be scavenged directly by ants, but fruit parts or arthropods associated with these deposits may provide nutrients for ants foraging in these caves.

\section{Cave foraging ants}

Cave foraging ants are either epigean species, which may include adventitious foraging in caves among their primarily epigean provisioning activities, or hypogeous species that live in the soil profile or epikarst, but that include caves that are integrated into their occupied habitat. The use of caves by ant colonies is primarily in the role of a trogloxene, where the ants include foraging in caves only as a portion of their overall provisioning behavior. This was recognized early on by Kempf (1961) and Wilson (1962). These colonies return their cave-garnered provisions to their nests located outside caves. Obviously, cave nutrients must be within the foraging range of the colony. Because of this, use of a given cave by ants may vary from year to year depending on the areal distribution of the colonies over time. This was evident for the $P$. rhea colony at Patagonia Bat Cave discussed previously.

Some of the more important ant genera using caves, such as Labidus, Neivamyrmex, and (probably) Nomamyrmex, already possess an innate hypogeous life style. Living in the soil profile or epikarst, these ants occupy thermally moderated, humid, aphotic habitats that are very similar to the cave environment. The New World tropical Cheliomyrmex, which are distinctly subterranean (Schneirla, 1971), have so far not been recorded from caves. This may be due to these ants being generally uncommon (Holldobler \& Wilson, 1990) or the lack of a proactive search effort, 
rather than an indication of their absence from caves.

The genus Neivamyrmex currently contains 131 described species (Kronauer, 2009; HOL), making it the largest group among the New World Dorylinae. There are currently 20 Neivamyrmex species known to occur in Arizona (AntWeb), four of which have been documented from caves in the state (Pape \& OConnor, 2014; this paper). As a group Neivamyrmex is predominantly hypogeic, with their bivouacs and predatory hunting activities mostly confined to subterranean habitats (Schneirla, 1971; Ryder Wilkie et al., 2007; Pacheco \& Vasconcelos, 2012). Surface activity levels vary among Neivamyrmex species, and are limited primarily to predatory raids, emigrations and reproductive flights conducted at night or on overcast days (Smith, 1942; Rettenmeyer, 1963). Neivamyrmex are primarily predators of other ant species or termites, but some species also take other arthropod prey including both soft and hard-bodied forms (Rettenmeyer, 1963; Schneirla, 1971; Mirenda et al., 1980; Holldobler \& Wilson, 1990; this paper).

Due to their nomadic, subterranean life style, Neivamyrmex may commonly intersect caves as they migrate through the soil and epikarst in karst terrains, and are probably more common in these environments than existing records might suggest. The earliest cave record for Neivamyrmex ( $N$. fallax Borgmeier) was from Cotterell Cave in Travis County, Texas, where its occurrence was presumed to be incidental (accidental) (Reddell \& Cokendolpher, 2001). Adding to the $N$. fallax record, two additional Neivamyrmex ( $N$. graciellae Mann, N. leonardi Wheeler) were recorded at Kartchner Caverns (Pape \& OConnor, 2014), and two more ( $N$. nigrescens and Neivamyrmex sp.) in Arkenstone Cave (this paper). These last four species records are the first evidence demonstrating the association of Neivamyrmex with the ecology of caves.

The ant that appears most prominently in cave records, the red imported fire ant ( $S$. invicta), is considered one of the 14 worst invasive alien insect species in the World (Lowe et al., 2004). S. invicta has been documented preying on a variety of arthropods in Texas caves, and is a significant threat to endemic cave animals (Elliott, 1992, 2000; Longacre, 2000; Taylor et al., 2005; Cokendolpher et al., 2009). S. invicta occurs in Texas as a non-native, invasive species, and has been recorded from well over 200 caves within a relatively small area in the central portion of the state (Reddell \& Cokendolpher, 2001). The large number of cave records for the species is mostly the result of extensive surveys in caves that are known to (or potentially) support more than a dozen endemic cave invertebrates that are listed as endangered under the ESA. While the Texas records for $S$. invicta are a special circumstance, in that they resulted from an extensive and concerted search effort, they demonstrate the potential for ants to affect the ecology of caves, in this case in a negative manner.

\section{Hypogeic ants and foraging depth in caves}

Subterranean army ants are a potentially significant threat to cave animals, particularly invertebrates, as documented for Neivamyrmex sp. at Arkenstone Cave
(Figs. $10 \& 11$ ). Army ant attacks on endemic cave invertebrates that have small populations or a limited distribution within a cave could result in adverse population-level impacts or extirpation of these animals. Since hypogeic army ants are at home in the subterranean environment, it would seem reasonable that they are capable of penetrating deeply into caves. The limited evidence we have so far, however, suggests that while they may travel substantial horizontal distances within caves, their movements seem to be vertically constrained.

Many army ant species prey primarily on other ant species, or on termites (Schneirla, 1971; Holldobler $\&$ Wilson, 1990). Deep substrate penetration is used by termites to obtain water or clay in areas where these resources are scarce. Termites have been found as deep as $70 \mathrm{~m}$, and are suggested to possibly seek water sources as deep as $100 \mathrm{~m}$ (Yakushev, 1968; Lee \& Wood, 1971; Cloud et al., 1980). However, the bulk of individuals within termite colonies typically occur in the top couple of meters of the soil horizon, where food resources are most abundant (Lee \& Wood, 1971; Matsumoto, 1976; Sheikh \& Kayani, 1982), and their numbers decrease significantly with depth (Yakushev, 1968). Ant nest depth varies among species and is, to a degree, a function of colony size (Buhl et al., 2004; Mikheyev \& Tschinkel, 2004; Tschinkel, 2004). Schneirla (1958) describes his excavation of a $N$. nigrescens bivouac within the galleries of a fungus ant in southern Arizona, which did not exceed one meter in depth. The larger, more permanent foraging trunk trails of the hypogeic Dorylus laevigatus Smith (Dorylinae) were found to typically occur at depths between 8 and $12 \mathrm{~cm}$ in the soil horizon in Malaysia (Berghoff et al., 2002). Other Dorylus nest at depths between 1 and $4 \mathrm{~m}$ (Gotwald, 1995). Other species, which are more hypogeous by nature, may excavate to somewhat greater depths. Nests of some larger ant colonies (e.g. Atta texana Buckley) have been recorded reaching as deep as $7.6 \mathrm{~m}$ within the soil horizon (Moser, 2006). These huge nest structures, which occur in several genera, are supported by colonies that may contain several million individuals (Holldobler \& Wilson, 1990). A majority of ant colonies are considerably smaller in scale and are typically concentrated much closer to the surface, usually within the upper three meters or so of the soil horizon (Antonialli \& Giannotti, 2001; Berghoff et al., 2002; Tschinkel, 2004, 2005, 2009; Bollazzi et al., 2008).

Foraging behavior of the more hypogeous army ant species likely co-evolved over time in concert with their mostly subterranean prey, and the habitats that these prey occupy. Since army ant prey abundance likely attenuates with depth in the soil horizon and epikarst, the evolved predatory foraging behavior of army ants may have become depth constrained to the approximate limits normally occupied by their prey.

Army ants periodically occupy prey nests between foraging episodes (Schneirla, 1958, 1971; Gotwald, 1995). While prey nest sites initially provide food for army ants, they also provide shelter, and minimize the need for them to construct nests. It is not known if, 
or to what extent, army ants may modify prey nests. Since such bivouacs are temporary for these nomadic animals, it seems likely that they would not make extensive modifications to these structures. This suggests that army ants may not excavate beyond the pre-existing limits of prey nests.

Another factor that may have molded army ant behavior over time, and may affect the vertical depth they will pursue prey, is the air chemistry within prey nests. The percentage of $\mathrm{O}_{2}$ and $\mathrm{CO}_{2}$ in the air within ant nests is normally in balance. Some ants have been observed to partition their age classes vertically within nests based on atmospheric concentrations of $\mathrm{CO}_{2}$, which increases significantly with depth in the nest, and furthest from surface connections where air exchange occurs (Kleineidam \& Roces, 2000; Tschinkel, 2004). When large numbers of marauding army ants enter their prey nest, activity of both the invaders and prey is increased to a high level of vigor. Oxygen is consumed at higher rates and carbon dioxide is increased in the atmosphere through respiration. The likely significant increase in $\mathrm{CO}_{2}$ concentration resulting from these struggles may make conditions in the deeper reaches of the nest marginally suitable during the brief times the invaders are present. The presence of inhospitable atmospheric conditions in the deeper reaches of prey nests, along with diminishing numbers of prey with vertical depth, may inhibit downward vertical predatory foraging in hypogeic ants.

Cave entrances allow animal movements into and out of caves, and are thus avenues of nutrient input to caves. These cave-surface interfaces commonly support a greater species richness and animal abundance than normally occur in cave interiors (Prous et al., 2004; Culver \& Pipan, 2014; Pape \& OConnor, 2014; Prous et al., 2015). One would expect ant colonies that occupy networks of cave passages to concentrate their activities near surface connections, where nutrients are likely to be more abundant.
This appears to be how $N$. graciellae is distributed within Kartchner Caverns (Fig. 1). Because of this, cave systems with multiple, closely-spaced surface connections should be a potentially ideal environment for cave-inhabiting army ant colonies.

$N$. graciellae has been observed active at depths ranging from 15 to $24 \mathrm{~m}$ below the surface at Kartchner Caverns. Measured depths include $16 \mathrm{~m}$ in the Tarantula Room area (C in Fig. 14), $24 \mathrm{~m}$ in the Red River Passage (B in Fig. 14), and $15 \mathrm{~m}$ in the Anticipation Room. N. graciellae is currently known to prey only on other ant species (Watkins \& Coody, Pape, 1986; this paper). The presence of this predator at depths well below where its prey is likely to occur, within the top couple of meters of the surface, would seem to be ineffectual behavior. However, an analysis of the structure of the cave relative to ant activities reveals that these in-cave depths are functionally artificial, and that the ants are not accessing the cave in a precipitous, vertical descent. N. graciellae probably primarily occupies the late Pleistocene alluvial deposits that overlie the lower portions of the bedrock pediment of the cave hill. Their activities within the cave are associated with subhorizontal access zones that are discontinuously situated at the periphery of the cave (Figs. $1 \& 14$; access zone). These access zones are comprised of the shallow surface alluvium and the contiguous consolidated soil sediments that were emplaced by gravity and autogenic meteoric waters in collapse, fault and fracture structures, and cave passages. Activities of $N$. graciellae in the cave seem to be concentrated in the vicinity of the Red River Passage, which is approximately $40 \mathrm{~m}$ from the surface of the cave hill along the presumed access zone shown in Fig. 14. This is the shortest distance from the cave that would allow the ants to reach the zone where their prey is presumed to occupy the alluvium overlying the cave. This suggests that army ants, even in a karst situation, do not normally penetrate

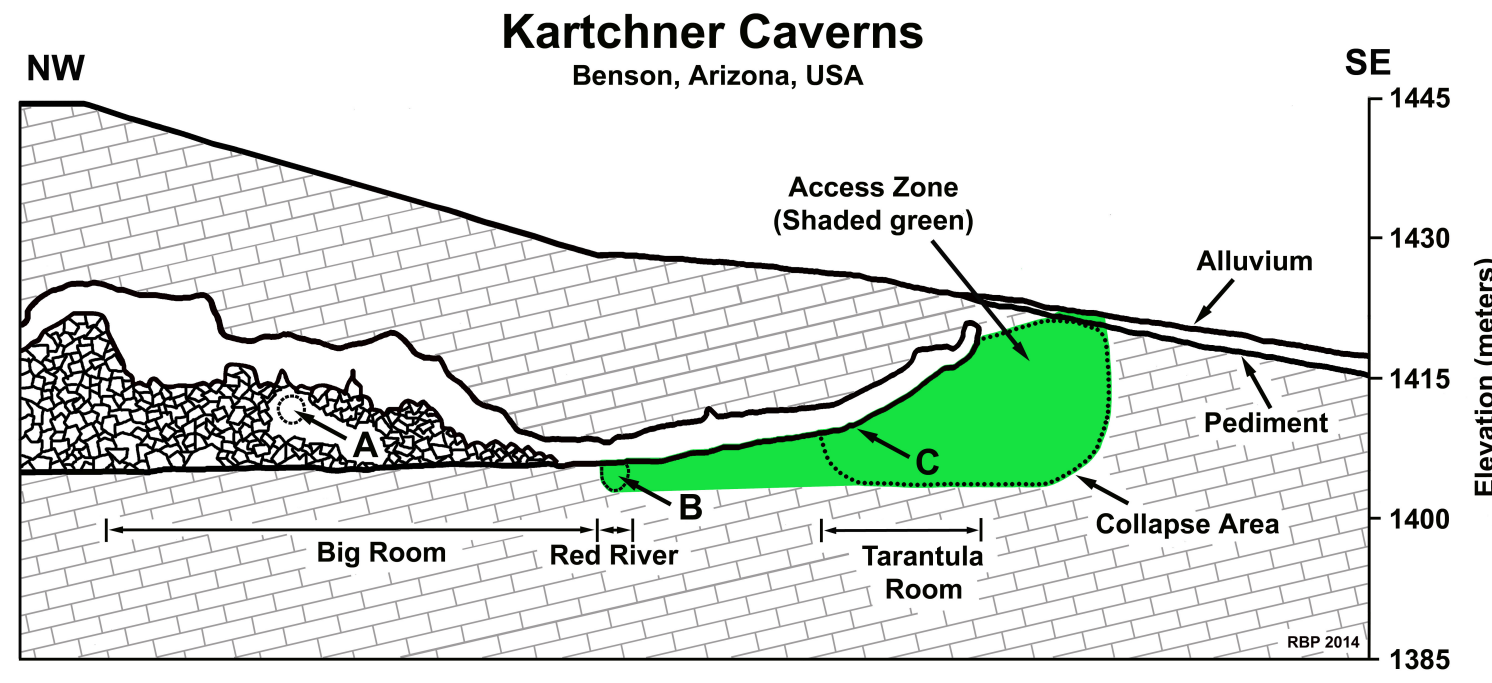

Fig. 14. Cross section of a portion of Kartchner Caverns (modified from Jagnow, 1999; with permission) showing relative depths for occurrences of Neivamyrmex leonardi and Neivamyrmex graciellae. The location for $N$. leonardi (A) in the Big Room, is the only record for the species in the cave. A typical access zone used by $N$. graciellae to enter the cave from the soil horizon is shown in green. Such access zones occur where incompetent areas of the cave hill pediment (collapse area in this figure; dotted line) are in contact with the overlying alluvium occupied by the ants. Two locations where N. graciellae has been observed in the cave are the Red River Passage (B) and the vicinity of the Tarantula Room (C). The Red River Passage is the center of activity for N. graciellae in the cave. 
to great vertical depth in search of prey, and that their activities may be mostly confined to horizontal underground movements.

$N$. leonardi is a small, delicate, pale and blind species, which probably has small colonies. The species is certainly less mobile than the larger, longer-legged $N$. graciellae, and probably has a smaller foraging range. $N$. leonardi was found deep within Kartchner Caverns, $28 \mathrm{~m}$ vertically and $130 \mathrm{~m}$ horizontally from the surface of the cave hill (Fig. 14). The combination of a presumed low mobility of this species, and its location deep within the cave suggests some potential exists that the colony may be eutroglophilic. A combination of small body size along with small colony size in ants occurring in caves was suggested by Tinaut \& Lopez (2001) as a possible evolutionary solution that might compensate for the large deme requirement in social insects that is usually unsupportable within oligotrophic cave habitats.

\section{Ecological groups, troglomorphy, and troglobiotic ants}

The ecological group assigned to ant colonies using caves should be a function of the nature and level of their association with these habitats, and not contingent on the presence of troglomorphy. Eutroglophiles and troglobionts do not always exhibit a readily apparent adaptive morphology (Romero, 2009, 2011; Pipan \& Culver, 2012; Pape, 2013). This is particularly true for those that have only recently adopted a cavernicolous existence (Pape, 2013). Isolation of animal populations in caves, which may eventually result in troglomorphy, can occur due to a variety of causes, including vicariance resulting from geophysical or hydrologic changes, changes in climate, or partitioning due to resource availability, competition, or predation (Coineau \& Boutin, 1992; Holsinger, 2000; Culver \& Pipan, 2009, 2014. Advanced troglomorphy is more evident in some other cave-occupying terrestrial arthropod taxa (Scorpionida, Pseudoscorpiones, Araneae, Opiliones) but, based on existing evidence, appears to be generally not well expressed in ants.

The reduced eyes and shortened appendages in primitive ants such as Amblyopone spp. suggest adaptation to aphotic environments early in ant evolution (Holldobler \& Wilson, 1990; Wilson \& Holldobler, 2005). However, few ant species exhibit significant loss of pigmentation, and even fewer show significant attenuation of the body, limbs or sensory structures present in many troglobionts. No known ant species exhibits extreme troglomorphy, as occurs in troglobionts in other taxonomic groups, where these morphologies co-evolved.

The fascination with troglomorphic, troglobiotic species gathers much attention from cave biologists (Pipan \& Culver, 2012; Prous et al., 2015), and the search for troglobiotic ant species has a long history. Very few ant species have been suggested as true cavernicoles, particularly where the association implies a troglobiotic life style. Most that have were eventually found to also occur in epigean habitats (Roncin \& Deharveng, 2003), and thus at most have occasional subtroglophilic colonies. Some of these are: Aphaenogaster cardenai Espadaler in Spain, Carebara (Oligomyrmex; Erebomyrma; Spelaeomyrmex) urichi Wheeler in Trinidad, and Hypoponera ragusai Santschi in Granada (Wilson, 1962; Tinaut, 2001; Tinaut \& Lopez, 2001; Roncin \& Deharveng, 2003). More recently, Ortuño et al. (2014) presented information regarding $A$. cardenai as an inhabitant of the mesovoid shallow substratum. They precluded A. cardenai as a eutroglophile (troglophile) based on its epigean reproductive dispersal behavior. This is likely a limiting factor for most ant colonies residing in caves, which could otherwise be considered eutroglophiles. Reddell suggested that Nylanderia (Paratrechina) pearsei Wheeler might be a troglobiotic species. This pale yellow, microphthalmic species is poorly known and has been recorded only from cave aphotic zones, typically found on moist flowstone or rock surfaces, or associated with drip pools (Reddell, 1977). Wheeler (1938), in his description of the species, referred to it as belonging to a small group of cavernicolous species. There have been no ecological studies of this species and its status is thus not currently established. The species may have subtroglophilic colonies.

Ant nesting activities have rarely been reported occurring in caves. Tinaut \& Lopez (2001) report three records of ants nesting in caves from the literature: Carebara urichi in Trinidad (Wilson, 1962); Lasius umbratus Nylander in Spain (Lopez Gomez, 1988); and Hypoponera ragusai in southern Spain (Tinaut, 2001). The bivouac records for $L$. coecus in Texas caves (Reddell \& Cokendolpher, 2001) could possibly also include statary phase bivouacs, which are the reproductive phase nests of army ants.

Wilson (1962) proposed that limitations are imposed on the evolution of troglobiotic forms in social insects by their need to form very large demes to support genetic viability and stability comparable with that found in non-social insects. He suggested that large demes would seldom be sustainable in cave environments due to the compounding factors of limitations on available nutrients and physical space (suitable habitat) present in these ecotopes. This likely explains why the preponderance of observations of ants found in caves has, until recently, not revealed any potentially troglobiotic forms.

The only ant species currently known that exhibits both a complex troglomorphy and an apparently strict cavernicolous habit is Leptogenys khammouanensis Roncin \& Deharveng, which lives deep within large caves in Laos (Roncin \& Deharveng, 2003). The species has reduced eyes with 15-20 ommatidia, the body color is a pale, orange-yellow, and the entire body form, including the legs and antennae, is moderately attenuated. L. khammouanensis is larger than other Leptogenys species, some of which have a morphology that suggests a subterranean evolution, but not necessarily a strict cavernicolous, or troglobiotic existence (Roncin \& Deharveng, 2003). Both dwarfism and gigantism occur occasionally in troglobiotic species (Vandel, 1965; Culver \& Pipan, 2009b; Trontelj et al., 2012), and the larger size of 
L. Khammouanensis, compared with its congeners, may be additional evidence of troglomorphy. While the ecology of this species has not been studied, it is possible that it may be the first truly troglobiotic ant species that has been found.

\section{SUMMARY}

The literature review revealed a diversity of ant subfamilies and genera occurring in caves globally, demonstrating their persistent presence in these habitats. The nature of the existing records, consisting of a high percentage of ancillary data, and likely skewed by an unintended emphasis of studies regionally, currently precludes meaningful analyses regarding any affinity for caves by discrete ant taxa, or regional prominence for the use of caves by ants.

This paper consolidates the 10 previously reported records of ants from five Arizona caves and adds 11 new records, for ten additional species, from five other Arizona caves. The new records are elements from a larger data set of biological surveys of macrobiotic fauna in 35 Arizona caves over a 25 year period. Ants were found in only six of the 35 caves studied. Survey efforts ranged from a single visit (Porcupine Cave) to 124 visits to a single cave over a 25-year period (Arkenstone Cave). Considering that the known cave resource in Arizona includes over 1,500 caves, the 35 caves visited represent a very small data set. Yet, based on this limited information it is apparent that ants play an important role in the ecology of some caves. It seems reasonable that similar behavior probably occurs on a global scale. This is particularly anticipated for the tropics, where ants are more diverse and there are greater available nutrient resources to support the animals in both epigean and cave environments. While the presence of ants in caves seems to generally occur at low levels, and may be sporadic, they are persistent in their presence in these habitats over time. The significance of cave habitats in providing both a suitable environment and nutrient sources for edaphic ant colonies is no longer in question. Observations of ant behavior in caves in Arizona ranged from simple foraging by scavenging species, such as Pheidole, to the large-scale marauding by Neivamyrmex sp. observed at Arkenstone Cave. Behavioral analysis of N. graciellae in Kartchner Caverns and Neivamyrmex sp. in Arkenstone Cave suggests that hypogeic army ants may not penetrate to great depth to search for prey, but can be persistent occupants of relatively shallow, horizontal sections of caves, where they may prey on endemic cave animals (Neivamyrmex sp.). Information contained within this paper will hopefully encourage researchers to reconsider the role of ants in cave ecosystems.

\section{ACKNOWLEDGMENTS}

I extend my greatest appreciation to Dr. Robert R. Casavant, Arizona State Parks Research and Science Manager and Cave Resource Manager at Kartchner
Caverns State Park for encouraging and permitting invertebrate studies within Kartchner Caverns. Dr. Casavant provided constructive comments that were incorporated into an earlier version of this paper.

I sincerely thank Steve Willsey, volunteer Senior Resource Specialist with the Arizona State Parks Research, Inventory and Monitoring program and retired Kartchner Caverns Cave Unit Ranger for his dedication to the Kartchner invertebrate studies through his assistance with field studies and project logistics. I thank KCSP personnel Mary Kumiega, Heidi Lauchstedt, Ginger Nolan, Erika Way and support staff for their interest in these studies and their steadfast stewardship efforts that keep the Kartchner Caverns ecosystem healthy and the cave open to public visitation. I thank Steve Willsey, Ellen Preiss, Esty Pape and Peter Kane for their assistance with survey work at Kartchner Caverns. I thank W. Eugene Hall/University of Arizona (UAIC) for identifying the Hyporhagus sp. beetle abdomen mentioned in the text.

I sincerely thank Martie, and the late Joe Maierhauser, long-term stewards and managers of Colossal Cave Mountain Park, for their friendship, encouragement, and permission to conduct research in the caves at CCMP over many years.

I thank William D. Peachey for providing the base maps for Arkenstone and Patagonia Bat Caves. I thank my wife Esty Pape, and my other caving comrades: William D. Peachey, Steve Willsey, Luis Espinasa, and Ray Keeler who accompanied me during the field work at various caves mentioned in this paper. I thank Esty Pape for proofreading the manuscript. I thank three anonymous reviewers of a previous version of this paper for their suggestions, the incorporation of which greatly improved this paper.

\section{REFERENCES}

Annandale N., Brown J.C. \& Gravely F.H., 1913 - The limestone caves of Burma and the Malay Peninsula. Journal and Proceedings of the Asiatic Society of Bengal, 9: 391-424.

Antonialli W.F. Jr. \& Giannotti E., 2001 - Nest architecture and population dynamics of the ponerine ant Ectatomma edentatum (Hymenoptera, Formicidae). Sociobiology, 38 (3A): 475-486.

AntWeb. http://www.antweb.org. [accessed: December 8, 2015].

Baroni Urbani C., 1962a - Studi sulla mirmecofauna d'Italia-I. Redia, 47: 129-138.

Baroni Urbani C., 1962b - Studi sulla mirmecofauna d'Italia-II. Formiche di Sicilia. Ricerche sulla fauna e sulla zoogeografia della Sicilia. Istituto di Zoologia dell' Universita di Catania, XXI: 25-66.

Barr T.C. Jr., 1967 - Ecological studies in the Mammoth Cave system of Kentucky I, The biota. International Journal of Speleology, 3: 147-204. http://dx.doi.org/10.5038/1827-806X.3.1.10

Batucan L.S. \& Nuñeza O.M., 2013 - Ant species richness in caves of Siargao Island Protected Landscape and Seascape, Philippines. ELBA Bioflux, 5 (2): 83-92.

Bellés X., 1987 - Fauna cavernicola $i$ intersticial de la Peninsula Ibérica i les Illes Balears. Consell Superior D’investigacions Científiques, Editorial Moll, Mallorca, 207 p. 
Berghoff S.M., Weissflog A., Linsenmair K.E., Hashim R. \& Maschwitz U., 2002 - Foraging of a hypogaeic army ant: a long neglected majority. Insectes Sociaux, 49: 133-141.

http://dx.doi.org/10.1007/s00040-002-8292-0

Bollazzi M., Kronenbitter J. \& Roces F., 2008 - Soil temperature, digging behavior, and the adaptive value of nest depth in South American species of Acromyrmex leaf-cutting ants. Oecologia, 158 (1): 165-175. http://dx.doi.org/10.1007/s00442-008-1113-z

Bolton B., 2014. An online catalog of the ants of the world. http://www.antcat.org/. [accessed: January 1, 2016].

Borgmeier T., 1937 - Formigas nova du pouco conhecidas da América do Sul e Central, principalmente do Brasil (Hymenoptera: Formicidae). Archivos do Instituto de Biologia Vegetal, 3: 217-255.

Braack L.E.O., 1989 - Arthropod inhabitants of a tropical cave "island" environment provisioned by bats. Biological Conservation, 48: 77-84.

http://dx.doi.org/10.1016/0006-3207(89)90027-X

Bracko G., 2006 - Review of the ant fauna (Hymenoptera: Formicidae) of Croatia. Acta Entomologica Slovenica, 14 (2): 131-156.

Brown D.E., 1982a - Madrean Evergreen Woodland. In: Brown D.E. (Ed.), Biotic Communities of the American Southwest-United States and Mexico. Desert Plants, 4 (1-4): 59-65.

Brown D.E., 1982b - Great Basin Conifer Woodland. In: Brown D.E. (Ed.), Biotic Communities of the American Southwest-United States and Mexico. Desert Plants, 4 (1-4): 52-57.

Brown D.E. \& Makings E., 2014 - A guide to North American grasslands. Desert Plants, 29 (2): 71-82.

Buecher D.C. \& Sidner R.M., 1999 - Bats of Kartchner Caverns State Park, Arizona. Journal of Cave and Karst Studies, 61 (2): 102-107.

Buhl J., Gautrais J., Deneubourg J. \& Theraulaz G., 2004 - Nest excavation in ants: group size effects on the size and structure of tunneling networks. Naturwissenschaften, 91: 602-606.

http://dx.doi.org/10.1007/s00114-004-0577-x

Camacho A.I., 1992 - A classification of the aquatic and terrestrial subterranean environment and their associated fauna. In: Camacho A.I. (Ed.), The natural history of biospeleology. Museo Nacional de Ciencias Naturales, Madrid, p. 57-103.

Chapman P., 1982 - The ecology of caves in the Gunung Mulu National Park, Sarawak. Cave Science, 9 (2): 142-162.

Clarke A., 2010 - An overview of invertebrate fauna collections from the Undara Lava Tube System. Proceedings $14^{\text {th }}$ International Symposium on Vulcanospeleology, Queensland, p. 59-76.

Cloud P., Gustafson L.B. \& Watson J.A.L., 1980 - The works of living social insects as pseudo fossils and the age of the oldest known metazoans. Science, 210 (4473): 1013-1015.

http://dx.doi.org/10.1126/science.210.4473.1013

Cockrum E.L., 1991 - Seasonal distribution of northwestern populations of the long-nosed bats, Leptonycteris sanborni family Phyllostomidae. Anales del Instituto de Biologia Universidad Nacional Autonoma de Mexico, Serie Zoologia, 62 (2): 181-202.

Cockrum E.L. \& Petryszyn Y., 1991 - The Long-nosed Bat, Leptonycteris: an endangered species in the southwest? Occasional Papers - The Museum - Texas Tech University, 142: 1-32.
Coineau N. \& Boutin C., 1992 - Biological processes in space and time - colonization, evolution and speciation in interstitial stygobionts. In: Camacho A.I. (Ed.), The natural history of biospeleology. Museo Nacional de Ciencias Naturales, Madrid, p. 423-451.

Cokendolpher J.C., 1990 - The ants (Hymenoptera, Formicidae) of Western Texas. part II. Subfamilies Ecitoninae, Ponerinae, Pseudomyrmecinae, Dolichoderinae, and Formicinae. Texas Tech University Press, Lubbock. Special publication 30, p. 1-76.

Cokendolpher J.C. \& Polyak V.J., 2004 - Macroscopic invertebrates of Hidden and Hidden Chimney caves, Eddy County, New Mexico. Speleological Monographs, 6: Texas Memorial Museum, Austin, p. 175-198.

Cokendolpher J.C., Reddell J.R., Taylor S.J., Krejca J.K., Suarez A.V. \& Pekins C.E., 2009 - Further ants (Hymenoptera: Formicidae) from caves of Texas. In: Cokendolpher J.C. \& Reddell J.R. (Eds.), Studies on the cave and endogean fauna of North America, $V$. Texas Memorial Museum Speleological Monographs, p. 151-168.

Cover S., 1989 - The Oropouche Cave revisited. Notes From Underground 2: 11-13.

Culver D.C. \& Pipan T., 2009a - The biology of caves and other subterranean habitats. Oxford University Press, New York, 254 p.

Culver D.C. \& Pipan T., 2009b - Caves, as islands. In: Gillespie R.G. \& Clague D.A. (Eds.), Encyclopedia of islands. Berkeley: University of California Press, Berkeley, p. 150-153.

Culver D.C. and Pipan T., 2014 - Shallow subterranean habitats - Ecology, evolution, and conservation. Oxford University Press, Oxford, 258 p. http://dx.doi.org/10.1093/acprof:oso/ 9780199646173.001.0001

Cunningham K.I., Northup D.E., Pollastro R.M., Wright W.G. \& LaRock E.J., 1995 - Bacteria, fungi and biokarst in Lechuguilla Cave, Carlsbad Caverns National Park, New Mexico. Environmental Geology, 25 (1): 2-8. http://dx.doi.org/10.1146/annurev.ecolsys.28.1.289

Dáttilo W., Vicente R.E., Nunes R.V. \& Feitosa R.M., 2012 - Influence of cave size and presence of bat guano on ant visitation. Sociobiology, 59 (2): 549-559.

http://dx.doi.org/10.13102/sociobiology.v59i2.617

Decu V., Casale A., Scaramozzino P.L., Lopez F. \& Tinaut A., 1998 - Hymenoptera. In: Juberthie C. \& Decu V. (Eds.), Encylopaedia Biospeologica II. Société de Biospéologie, Moulis, p. 1015-1024.

Deharveng L. \& Bedos A., 2000 - The cave fauna of southeast Asia. Origin, evolution and ecology. In: Wilkens H., Culver D.C. \& Humphreys W.F. (Eds.), Subterranean ecosystems. Elsevier, Amsterdam, p. 603-632.

Elliott W.R., 1992 - The imported fire ant in Texas caves. National Speleological Society Bulletin, 54 (2): 83-84.

Elliott W.R., 2000 - Conservation of the North American cave and karst biota. In: Wilkens H., Culver D.C. \& Humphreys W.F. (Eds.), Ecosystems of the World (30). Subterranean Ecosystems. Elsevier, New York, p. 665-689.

Espadaler X., 1983 - Sobre formigues trobades en coves (Hymenoptera, Formicidae). Speleon 26/27: 53-56.

Ferreira R.L. \& Martins R.P., 1999 - Trophic structure and natural history of bat guano invertebrate communities, with special reference to Brazilian caves. Tropical Zoology, 12 (2): 231-252. http://dx.doi.org/10.1080/03946975.1999.10539391

Ferreira R.L., Prous X. \& Martins R.P., 2007 - Structure of bat guano communities in a dry Brazilian cave. Tropical Zoology, 20: 55-74. 
Figueras G.S. \& Nuňeza O.M., 2013 - Species diversity of ants in karst limestone habitats in Bukidnon and Davao Oriental, Mindanao, Philippines. AES Bioflux 5 (3): 306-315.

Framenau V.W. \& Thomas M.L., 2008 - Ants (Hymenoptera: Formicidae) of Christmas Island (Indian Ocean): identification and distribution. Records of the Western Australian Museum, 25: 45-85. http://dx.doi.org/10.18195/issn.0312-3162.25(1). 2008.045-085

Franciscolo M.E., 1955 - Fauna cavernicola del Savonese. Annali del Museo Civico di Storia Naturale - Giacomo Doria (Res Ligusticae 94), 67: 1-223.

Gotwald Jr. W.H., 1995 - Army ants. The biology of social predation. Cornell University Press, Ithaca, $302 \mathrm{p}$.

Hoffmeister D.F., 1986 - Mammals of Arizona. University of Arizona Press, Tucson, 602 p.

HOL - Hymenoptera Online. http://hol.osu.edu. [accessed: December 29, 2012].

Holland R.A., Wikelski M., Kümmeth F., \& Bosque C., 2009 - The secret life of oilbirds: new insights into the movement ecology of a unique avian frugivore. PLoS ONE, 4 (12): e8264.

http:/ / dx.doi.org/10.1371/journal.pone.0008264

Holldobler B. \& Wilson E.O., 1990 - The ants. Harvard University Press, Cambridge, $732 \mathrm{p}$.

http://dx.doi.org/10.1007/978-3-662-10306-7

Holsinger J.R., 2000 - Ecological derivation, colonization, and speciation. In: Wilkens H., Culver D.C. \& Humphreys W.F. (Eds.), Subterranean ecosystems. Elsevier, Amsterdam, p. 399-415.

Howarth F.G., 1983 - Ecology of cave arthropods. Annual Review of Entomology, 28: 365-389.

http://dx.doi.org/10.1146/annurev.en.28.010183.002053

Howarth F.G., James S.A., McDowell W., Preston D.J. \& Imada C.T., 2007 - Identification of roots in lava tube caves using molecular techniques: implications for conservation of cave arthropod faunas. Journal of Insect Science, 11 (3): 251-261.

http://dx.doi.org/10.1007/s10841-006-9040-y

Hubbell T.H. \& Norton R.M., - 1978. The systematics and biology of the cave-crickets of the North American Tribe Hadenoecini (Orthoptera Saltatoria: Ensifera: Rhaphidophoridae: Dolichopodinae). Miscellaneous Publication of the Museum of Zoology, University of Michigan, No. 156.

Humphreys W.F., 1998 - Phaconeura (Homoptera: Meenoplidae) attended by ants of the genus Paratrechina (Hymenoptera: Formicidae) in caves. The Australian Entomologist, 25: 23-27.

Humphreys W.F. \& Eberhard S., 2001 - Subterranean fauna of Christmas Island, Indian Ocean. Helictite, 37 (2): 59-74.

Hung A.C.F., 1970 - A revision of the ants of the subgenus Polyrachis Fr. Smith (Hymenoptera: Formicidae: Formicinae). Oriental Insects, 4 (1): 1-36. http://dx.doi.org/10.1080/00305316.1970.10433938

Hüppop K., 2000 - How do cave animals cope with the food scarcity in caves? In: Wilkens H., Culver D.C. \& Humphreys W.F. (Eds.), Ecosystems of the World (30). Subterranean Ecosystems. Elsevier, New York, p. 159-188.

Jagnow D.H., 1999 - Geology of Kartchner Caverns State Park, Arizona. Journal of Cave and Karst Studies, 61 (2): 49-58.

Juberthie C., 2000 - The diversity of the karstic and pseudokarstic hypogean habitats in the World. In: Wilkens H., Culver D.C. \& Humphreys W.F. (Eds.), Ecosystems of the World (30). Subterranean Ecosystems. Elsevier, New York, p. 665-689.
Juberthie C., Delay B. \& Bouillon M., 1980 - Sur l'existence d'un milieu souterrain superficiel en zone non-calcaire. Comptes rendus des séances de la Société de biologie Paris, 290: 49-52.

Kempf W.W., 1961 - Labidus coecus as a cave ant. Studia Entomologica, 4: 551-552.

Kleineidam C. \& Roces F., 2000 - Carbon dioxide concentrations and nest ventilation in nests of the leaf-cutting ant Atta vollenweideri. Insectes Sociaux, 47: 241-248. http://dx.doi.org/10.1007/PL00001710

Kronauer D.J.C., 2009 - Recent advances in army ant biology (Hymenoptera: Formicidae). Myrmecological News, 12: 51-65.

Lapeva-Gjonova A., Antonova V., Radchenko A.G. \& Atanasova M., 2010 - Catalogue of the ants (Hymenoptera, Formicidae) of Bulgaria. Zookeys, 62: 1-124. http://dx.doi.org/10.3897/zookeys.62.430

LaPolla J.S., Mueller U.G., Seid M. \& Cover S.P., 2002 - Predation by the army ant Neivamyrmex rugulosus on the fungus-growing ant Trachymyrmex arizonensis. Insectes Sociaux, 49: 251-256.

http://dx.doi.org/10.1007/s00040-002-8310-2

Lavoie K.H., Helf K.L. \& Poulson T.L., - 2007. The biology and ecology of North American cave crickets. Journal of Cave and Karst Studies, 69 (1): 114-134.

Lee K.E. \& Wood T.T., 1971 - Termites and soils. Academic Press, New York, 251 p.

Longacre C. 2000. Endangered and threatened wildlife and plants; final rule to list nine Bexar County, Texas Invertebrate species as endangered. Federal Register, Department of the Interior, Fish and Wildlife Service, 50 CFR part 17, RIN 1018-AF33.65(248): 81419-81433.

Lopez Gomez F., 1988 - Descripcion de un nido de Lasius umbratus (Nylander, 1864) encontrado en el interior de una cueva y algunas considerciones sobre el caracter cavernicola de las hormigas (Hym., Formicidae). Mémoires de Biospéologie, 15: 107-115.

Lowe S., Browne M., Boudjelus S. \& De Poorter M., 2004 - 100 of the World's worst invasive alien species. A selection from the Global Invasive Species Database. http://www.issg.org/pdf/publications/worst 100/ english_100_worst.pdf. [accessed: February 9, 2013].

Lunghi E., Manenti R. \& Ficetola G.F., 2014 - Do cave features affect underground habitat exploration by nontroglobite species? Acta Oecologica, 55: 29-35. http://dx.doi.org/10.1016/j.actao.2013.11.003

Mackay W.P. \& Mackay E., 2002 - Ants of New Mexico. Edwin Mellen Press, Lewiston, 398 p.

Martín J.L., Oromí P. \& Barquín J., 1985 - Estudio ecológico del ecosistema cavernícola de una sima de origen volcánico: La Sima Robada (Tenerife, Islas Canarias). Endins, 10-11: 37-46.

Matsumoto T., 1976 - The role of termites in an equatorial rain forest ecosystem of West Malaysia. 1. Population density, biomass, carbon, nitrogen and calorific content and respiration rate. Oecologia, 22 (2): 153-178. http://dx.doi.org/10.1007/BF00344714

McClure H.E., Lim B. \& Winn S.E., 1967 - Fauna of the Dark Cave, Batu Caves, Kuala Lumpur, Malaysia. Pacific Insects, 9 (3): 399-428.

Mei M., 1992 - Su alcune specie endogee o criptobiotiche della mirmecofauna Italiana (Hymenoptera, Formicidae). Fragmenta Entomologica 23 (2): 411-422.

Mikheyev A.S. \& Tschinkel W.R., 2004 - Nest architecture of the ant Formica pallidefulva: structure, costs and rules of excavation. Insectes Sociaux, 51: 30-36. http:/ / dx.doi.org/10.1007/s00040-003-0703-3

Mirenda J.T., Eakins D.G., Gravelle K. \& Topoff H., 1980 - Predatory behavior and prey selection by army ants in a desert-grassland habitat. Behavioral Ecology and Sociobiology, 7 (2): 119-127.

http:/ /link.springer.com/article/10.1007/BF00299517 
Mizutani H., D.A. McFarlane D.A. \& Kabaya Y., 1992 Nitrogen and carbon isotope studies of a bat guano core from Eagle Creek Cave, Arizona, USA. Journal of the Mass Spectrometry Society of Japan, 40 (1): 57-65. http://dx.doi.org/10.5702/massspec.40.57

Moser J.C., 2006 - Complete excavation and mapping of a Texas leafcutting ant nest. Annals of the Entomological Society of America, 99 (5): 891-897. http://dx.doi.org/10.1603/0013-8746(2006)99\%5B8 91:CEAMOA\%5D2.0.CO;2

Moulds T., 2004 - Review of Australian cave guano ecosystems with a checklist of guano invertebrates. Proceedings of the Linnean Society of New South Wales, 125: 1-42.

Moulds T., 2006 - The first Australian record of subterranean guano-collecting ants. Helictite, 39 (1): 3-4.

Muchmore W.B. \& Pape R.B., 1999 - Description of an eyeless. cavernicolous Albiorix (Pseudoscorpionida: Ideoroncidae) in Arizona, with observations on its biology and ecology. Southwestern Naturalist, 44 (2): 138-147.

Müller G., 1923 - Le formiche della Venezia Giulia e della Dalmazia. Bollettino della Societal Adriatica di Scienze de Natumli, 11-180.

Ortiz M., Legatzki A., Neilson J.W., Fryslie B., Nelson W.M., Wing R.A., Soderlund C.A., Pryor B.M. \& Maier R.M., 2013 - Making a living while starving in the dark: metagenomic insights into the energy dynamics of a carbonate cave. ISME Journal, September 12, 2013: 1-14. http://dx.doi.org/10.1038/ismej.2013.159

Ortuño V.M., Gilgado J.D. \& Tinaut A., 2014 Subterranean ants: the case of Aphaenogaster cardenai (Hymenoptera: Formicidae). Journal of Insect Science, 14 (212): 1-7. http://dx.doi.org/10.1093/jisesa/ieu074

Pacheco R. \& Vasconcelos H.L., 2012 - Subterranean pitfall traps: is it worth including them in your ant sampling protocol? Psyche, 2012 (870794).

http://dx.doi.org/10.1155/2012/870794

Packard A.S., 1888 - The cave fauna of North America, with remarks on the anatomy of the brain and origin of the blind species. Memoirs of the National Academy of Sciences, 4 (1): 1-156. http://dx.doi.org/10.5962/bhl.title.51841

Pape R.B., 2013 - Description and ecology of a new cavernicolous, arachnophilous thread-legged bug (Reduviidae: Emesini) from Kartchner Caverns, Cochise County, Arizona. Zootaxa, 3670 (2): 137-156. http://dx.doi.org/10.11646/zootaxa.3670.2.2

Pape R.B., 2014 - Biology and ecology of Bat Cave, Grand Canyon National Park, Arizona. Journal of Cave and Karst Studies, 76 (1): 1-13.

http://dx.doi.org/10.4311/20121sc0266

Pape R.B. \& OConnor B.M., 2014 - Diversity and ecology of the macro-invertebrate fauna (Nemata and Arthropoda) of Kartchner Caverns, Cochise County, Arizona, United States of America. CheckList Journal, 10 (4): 761-794. http://dx.doi.org/10.15560/10.4.761

Pase C.P. \& Brown D.E., 1982 - Rocky Mountain (Petran) and Madrean Montane Conifer Forest. In: Brown D.E. (Ed.), Biotic Communities of the American SouthwestUnited States and Mexico. Desert Plants, 4 (1-4): 43-48.

Peck S.B., 1974 - The invertebrate fauna of tropical American caves, part II: Puerto Rico, An ecological and zoogeographic analysis. Biotropica, 6 (1): 14-31.

http://dx.doi.org/10.2307/2989693

Peck S.B., 1981a - Community composition and zoogeography of the invertebrate cave fauna of Barbados. Florida Entomologist, 64 (4): 519-527.

http://dx.doi.org/10.2307/3494409
Peck S.B., 1981b - Zoogeography of invertebrate cave faunas in southwestern Puerto Rico. National Speleological Society Bulletin, 43 (3): 70-79.

Peck S.B., 1982 - A contribution to the knowledge of the invertebrate cave faunas of Venezuela: Invertebrate faunas of tropical American caves, part 4. International Journal of Speleology, 12: 75-81. http://dx.doi.org/10.5038/1827-806X.12.1.8

Peck, S.B., 1992 - A synopsis of the invertebrate cave fauna of Jamaica. National Speleological Society Bulletin, 54 (2): 37-60.

Pipan T. \& Culver D.C., 2012 - Convergence and divergence in the subterranean realm: a reassessment. Biological Journal of the Linnean Society, 107: 1-14. http://dx.doi.org/10.1111/j.1095-8312.2012.01964.x

Polis G.A., Anderson W.B. \& Holt R.D., 1997 - Towards an integration of landscape and food web ecology: The dynamics of spatially subsidized food webs. Annual Review of Ecology and Systematics, 28: 289-316.

http:/ /dx.doi.org/10.1146/annurev.ecolsys.28.1.289

Poulson T.L., 1992 - The Mammoth Cave ecosystem. In: Camacho A. (Ed.), The natural history of biospeleology: Madrid Museo Nacional de Ciencias Naturales, Madrid, Spain, p. 568-611.

Prous X., Ferreira R.L. \& Jacobi C.M., 2015 - The entrance as a complex ecotone in a Neotropical cave. International Journal of Speleology, 44 (2): 177-189. http://dx.doi.org/10.5038/1827-806X.44.2.7

Prous X., Ferrerira R.L. \& Martins R.P., 2004 - Ecotone delimitation: Epigean-hypogean transition in cave ecosystems. Austral Ecology, 29 (4): 374-382. http://dx.doi.org/10.1111/j.1442-9993.2004.01373.x

Rabeling C., Cover S.P., Johnson R.A. \& Mueller U.G., 2007 - A review of the North American species of the fungus-gardening ant genus Trachymyrmex (Hymenoptera: Formicidae). Zootaxa, 1664: 1-53.

Reddell J.R., 1977 - A preliminary survey of the caves of the Yucatan peninsula. In: Reddell J.R. (Ed.), Studies on the caves and cave fauna of the Yucatan peninsula. Association for Mexican Cave Studies Bulletin (6). The Speleo Press, Austin, p. 215-296.

Reddell J.R., 1982 - A checklist of the cave fauna of Mexico VII. Northern Mexico. In: Reddell J.R. (Ed.), Further studies on the cavernicole fauna of Mexico and adjacent regions. Association for Mexican Cave Studies, Bulletin (28). The Speleo Press, Austin, p. 249-283.

Reddell J.R. \& Cokendolpher J.C., 2001 - Ants (Hymenoptera: Formicidae) from the caves of Belize, Mexico, and California and Texas (U.S.A.). In: Reddell J.R. \& Cokendolpher J.C. (Eds.), Studies on the cave and endogean fauna of North America III. Texas Memorial Museum Speleological Monograph, 5, p. 129-154.

Reddell J.R. \& Mitchell R.W., 1971a - A checklist of the cave fauna of Mexico I. Sierra del Abra, Tamaulipas and San Luis Potosi. In: Reddell J.R. \& Mitchell R.W. (Eds.), Studies on the cavernicole fauna of Mexico Association for Mexican Cave Studies Bulletin 4: 137-180.

Reddell J.R. \& Mitchell R.W., 1971b - A checklist of the cave fauna of Mexico II. Sierra de Guatemala. Tamaulipas. In: Reddell J.R. \& Mitchell R.W. (Eds.), Studies on the cavernicole fauna of Mexico. Association for Mexican Cave Studies, Bulletin 4: 181-215.

Reddell J.R. \& Mitchell R.W., 1971c - A checklist of the cave fauna of Mexico III. New records from southern Mexico. In: Reddell J.R. \& Mitchell R.W. (Eds.), Studies on the cavernicole fauna of Mexico. Association for Mexican Cave Studies, Bulletin 4: 217-230.

Reddell J.R. \& Veni G., 1996 - Biology of the Chiquibul Cave System, Belize and Guatemala. Journal of Cave and Karst Studies, 58 (2): 131-138. 
Reeves W.K., 2000 - Invertebrate cavernicoles of the Great Smoky Mountains National Park, USA. Journal of the Elisha Mitchell Scientific Society, 116: 334-343.

Reeves W.K., Jensen J.B. \& Ozier J.C., 2000 - New faunal and fungal records from caves in Georgia, USA. Journal of Cave and Karst Studies, 62 (3): 169-179.

Rettenmeyer C.W., 1963 - Behavioral studies of army ants. University of Kansas Science Bulletin, 44: 281-465.

Rigato F. and Toni I., 2011 - Hymenoptera, Formicidae. In: Nardi G.,Whitmore D., Bardiani M., Birtele D., Mason F., Spada L., \& Cerretti P. (Eds.), Biodiversity of Marganai and Montimannu (Sardinia). Research in the framework of the ICP Forests network. Conservazione Habitat Invertebrati 5. Centro Nazionale per lo Studio e la Conservazione della Biodiversità Forestale "Bosco Fontana" di Verona, Verona, p. 873-882.

Romero A., 2009 - Cave biology-life in darkness. Cambridge University Press, Cambridge, 291 p. http://dx.doi.org/10.1017/CBO9780511596841

Romero A., 2011 - The Evolution of Cave Life - New concepts are challenging conventional ideas about life underground. American Scientist, 99: 144-151.

http://dx.doi.org/10.1511/2011.89.144

Roncin E. \& Deharveng L., 2003 - Leptogenys khammouanensis sp. nov. (Hymenoptera: Formicidae). A possible troglobitic species of Laos, with a discussion on cave ants. Zoological Science, 20: 919-924. http://dx.doi.org/10.2108/zsj.20.919

Roth J., 2001 - Subterranean species of the US and Canada. Draft database on CD ROM, October 2001. Available from: ORCA_Resource_Management@nps.gov

Ryder Wilkie K.T., Mertl A.L. \& Traniello J.F., 2007 Biodiversity below ground: probing the subterranean ant fauna of Amazonia. Naturwissenschaften, 94 (9): 725-731. http://dx.doi.org/10.1007/s00114-007-0250-2

Schembri S.P. \& Collingwood C.A., 1981 - A revision of the myrmecofauna of the Maltese Islands (Hymenoptera, Formicidae). Annali del Museo Civico di Storia Naturale Giacomo Doria (Genova), 83: 417-442.

Schneirla T.C., 1958 - The behavior and biology of certain Nearctic army ants - last part of the functional season, southeastern, Arizona. Insectes Sociaux, 2: 215-255. http://dx.doi.org/10.1007/BF02224071

Schneirla T.C., 1971 - Army ants, a study in social organization. W.H. Freeman and Company, San Francisco, 349 p.

Sendra A., Achurra A., Barranco P., Beruete E., Borges P.A.V., Herrero-Borgoñón J.J., Camacho A.I., Galán C., Garcia L.I., Jaume D., Jordana R., Modesto J., Monsalve M.A., Oromi P., Ortuño V.M., Prieto C., Reboleira A.S., Rodriquez P., Salgado J.M., Teruel S., Tinaut A. \& Zaragosa J.A., 2011 - Biodiversidad, regiones biogeográficas y conservación de la fauna subterránea hispano-lusa. Boletín de la Sociedad Entomológica Aragonesa (S.E.A.) 49: 365-400.

Shear W.A., Taylor S.J., Wynne J.J. \& Krejca JK., 2009 - Cave millipeds of the United States VIII. New genera and species of polydesmidan millipeds from caves in the southwestern United States (Diplopoda, Polydesmida, Macrosternodesmidae). Zootaxa, 2151: 47-65.

Sheikh K.H. \& Kayani S.A., 1982 - Termite-affected soils in Pakistan. Soil Biology and Biochemistry, 14 (4): 359-364.

http://dx.doi.org/10.1016/0038-0717(82)90006-2

Sket B., 2008 - Can we agree on an ecological classification of subterranean animals?, Journal of Natural History, 42 (21-22): 1549-1563.

http://dx.doi.org/10.1080/00222930801995762
Smith M.R., 1942 - The legionary ants of the United States belonging to Eciton subgenus Neivamyrmex Borgmeier. American Midland Naturalist, 27 (3): 537-590. http://dx.doi.org/10.2307/2420913

Snelling G.C. \& Snelling R.R. - New World army ants. http://www.armyants.org. [accessed: January 10, 2014].

Snelling G.C. \& Snelling R.R., 2007 - New synonymy, new species, new keys to Neivamyrmex army ants of the United States. In: Snelling R.R., Fisher B.L. $\&$ Ward P.S. (Eds.), Advances in ant systematics (Hymenoptera: Formicidae): homage to E.O. Wilson 50 years of contributions. Memoirs of the American Entomological Institute. American Entomological Institute, Gainesville, p. 459-550.

Taylor S.J., Krejca J.K. \& Denight M.L., 2005 - Foraging range and habitat use of Ceuthophilus secretus (Orthoptera: Rhaphidophoridae), a key trogloxene in central Texas cave communities. American Midland Naturalist, 154: 97-114.

http://dx.doi.org/10.1674/0003-0031(2005)154\% 5B0097:FRAHUO\%5D2.0.CO;2

Tinaut A., 2001 - Hypoponera ragusai (Emery, 1895) a cavernicolous ant new for the Iberian Peninsula (Hymenoptera, Formicidae). Graellsia, 57 (1): 3-8. http://dx.doi.org/10.3989/graellsia.2001.v57.i1.290

Tinaut A. \& Lopez, F., 2001 - Ants and caves: sociability and ecological constraints (Hymenoptera, Formicidae). Sociobiology, 37: 651-659.

Trajano E., 1987 - Fauna cavernícola Brasileira: Composiçao e caracterização preliminar. Revista Brasileira de Zoologia, 3 (8): 533-561.

Trajano E., 2000 - Cave faunas in the Atlantic tropical rain forest: composition, ecology, and conservation. Biotropica, 32 (4b): 882-893.

http://dx.doi.org/10.1111/j.1744-7429.2000.tb00626.x

Trajano E. \& Bichuette M.E., 2009 - Diversity of Brazilian subterranean invertebrates, with a list of troglomorphic taxa. Subterranean Biology, 7: 1-16.

Trontelj P., Blejec A. \& Fišer C., 2012 - Ecomorphological convergence of cave communities. Evolution, 66 (12): 3852-3865.

http://dx.doi.org/10.1111/j.1558-5646.2012.01734.x

Tschinkel W.R., 2004 - The nest architecture of the Florida harvester ant, Pogonomyrmex badius. Journal of Insect Science, 4 (21): 1-19.

http:/ / dx.doi.org/10.1093/jis/4.1.21

Tschinkel W.R., 2005 - The nest architecture of the ant, Camponotus socius. Journal of Insect Science, 5 (9): 1-18.

http://dx.doi.org/10.1093/jis/5.1.9

Tschinkel W.R., 2009 - The nest architecture of three species of north Florida Aphenogaster ants. Journal of Insect Science, 11 (105): 1-30.

Turner R.M. \& Brown D.E., 1982 - Sonoran Desertscrub. In: Brown D.E. (Ed.), Biotic Communities of the American Southwest-United States and Mexico. Desert Plants, 4 (1-4): 181-211.

United States Fish and Wildlife Service (USFWS), 1995 Lesser long-nosed bat recovery plan. United States Fish and Wildlife Service, Albuquerque, New Mexico, 45 p.

Vandel A., 1965 - Biospeleology. The biology of cavernicolous animals. Pergamon Press, New York, 524 p.

Vo T.L., Mueller U.G. \& Mikheyev A.S., 2009 - Free-living fungal symbionts (Lepiotaceae) of fungus-growing ants (Attini: Formicidae). Mycologia, 101 (2): 206-210. http://dx.doi.org/10.3852/07-055

Ward P.S., 2014 - The phylogeny and evolution of ants. Annual Review of Ecology, Evolution, and Systematics, 45: $23-43$.

http://dx.doi.org/10.1146/annurev-ecolsys-120213$\underline{091824}$ 
Watkins J.F., II., 1985 - The identification and distribution of the army ants of the United States of America (Hymenoptera, Formicidae, Ecitoninae). Journal of the Kansas Entomological Society, 58 (3): 479-502.

Watkins J.F. \& Coody C.J., 1986 - The taxonomy of Neivamyrmex graciellae (Mann) (Hymenoptera: Formicidae: Ecitoninae) including an original description of the queen and field observations. Southwestern Naturalist, 31 (2): 256-259.

Weber N.A., 1943 - New ants from Venezuela and neighboring countries. Boletin de Entomologia Venezolana, 2 (2): 67-78.

Weinstein P. \& Slaney D., 1995 - Invertebrate faunal survey of Rope Ladder Cave, Northern Queensland: a comparative study of sampling methods. Australian Journal of Entomology, 34: 233-236.

http://dx.doi.org/10.1111/j.1440-6055.1995.tb01329.x

Welbourn W.C., 1999 - Invertebrate cave fauna of Kartchner Caverns, Kartchner Caverns, Arizona. Journal of Cave and Karst Studies, 61 (2): 93-101.

Wetterer J.K., Espadaler X., Ashmole N.P., Mendel H., Cutler C. \& Endeman J., 2007 - Ants (Hymenoptera: Formicidae) of the South Atlantic islands of Ascension Island, St. Helena, and Tristan da Cunha. Myrmecological News, 10: 29-37.

Wetterer J.K., Espadaler X., Wetterer A.L. \& Cabral G.M., 2004 - Native and exotic ants of the Azores (Hymenoptera: Formicidae). Sociobiology, 44 (1): 1-19.

Wheeler W.M., 1922 - The ants of Trinidad. American Museum Novitates, 45: 1-16.

Wheeler W.M., 1924 - Hymenoptera of the Siju Cave, Garo Hills, Assam, Part I: Triglyphothrix striatidens Emery as a cave ant. Records of the Indian Museum, 26: 123-124.
Wheeler W.M., 1927 - Ants of the genus Amblyopone Erichson. Proceedings of the American Academy of Arts and Sciences, 62: 1-29.

http://dx.doi.org/10.2307/25130101

Wheeler W.M., 1938 - Ants from the caves of Yucatan. In: Pearse A.S. (Ed.), Fauna of the caves of Yucatan. Publication 491. Carnegie Institution of Washington, Washington, p. 251-255.

Wilson E.O., 1955 - A monographic revision of the ant genus Lasius. Bulletin of the Museum of Comparative Zoology, 113 (1): 1-198.

Wilson E.O., 1962 - The Trinidad cave and Erebomyrma (=Spelaeomyrmex) urichi (Wheeler), with a comment on cavernicolous ants in general. Psyche, 69: 62-72. http://dx.doi.org/10.1155/1962/54863

Wilson E.O., 2003 - Pheidole in the New World. Harvard University Press, London, 794 p.

Wilson E.O. \& Holldobler B. 2005 - The rise of the ants: A phylogenetic and ecological explanation. Proceedings of the National Academy of Sciences, 102 (21): 7411-7414. http://dx.doi.org/10.1073/pnas.0502264102

Wynne J.J., 2013 - Inventory, conservation and management of lava tube caves at El Malpais National Monument, New Mexico. National Park Service-Park Science 30 (1): Appendix A-1: 45-55.

Wynne J.J. \& Voyles K.D., 2014 - Cave-dwelling arthropods and vertebrates of north rim Grand Canyon, with notes on ecology and management. Western North American Naturalist, 74 (1): 1-17.

http://dx.doi.org/10.3398/064.074.0102

Yakushev V.M., 1968 - Influence of termite activity on the development of laterite soil. Soviet Soil Science, 1: 109-111. 